Int. J. Speleol. 21 1-4 (1992), pp. 1

\title{
MORPHOMETRIC ANALYSIS OF DOLINES
}

\section{FLORIDA STATE UNIVESITY LIBRARIES}

\author{
A.Bondesan*, M.Meneghel* and U.Sauro*
}

\author{
MAR 81995
}

SUMMARY

TALLAHASSEE, FLORIDA

General key words: doline, morphometry, spatial analysis.

Regional key words: Venetian Prealps, Cansiglio-Cavallo, Montello, Carso di Trieste.

The doline is the most specific surface form of karst landscapes, which enables one to distinguish them from "normal" erosion landscapes shaped by surface water. From a morphodynamic point of view the doline constitutes an elementary hydrographic unit, comparable to a simple basin, which, with its system of slopes, conveys water to the absorbing points at the bottom into an underground network.

The morphometric study of these karst landforms enables a quantitative analysis of karst environment. Comparisons of the various parameters may give unexpected results and lead to new hypotheses about the evolution and the dynamism of the karst "geo-ecosystem".

All the main morphometric parameters of the dolines are listed and explained and a preliminary discussion about some methods of spatial analysis is developed.

It is intended to give methodological suggestions about data sources, systems of measurement, and to stimulate some reflection on the choices of possible processing of morphometric variables and on the significance of statistical analysis applied to different parameters.

After a brief review of some morphometric and spatial analyses made in the past by different authors, three different examples are presented, relative to karst areas of the Venetian Prealps (Cansiglio-Cavallo, Montello) and of the Carso di Trieste. From these few examples one can understand how to confront this complex subject and what kind of results the analysis of morphometric parameters may give. In interpretating the results it is evident that one

* Department of Geography, University of Padua, via del Santo, 26 I-35123 Padova (Italy) 
must not forget the geological, geomorphological, pedological, vegetational and climatic context of the karst area.

\section{RIASSUNTO}

Termini chiave: dolina, morfometria, analisi spaziale.

Termini chiave regionali: Prealpi Venete, Cansiglio-Cavallo, Montello, Carso di Trieste.

La dolina è la forma superficiale più specifica dei paesaggi carsici, che permette di distinguerli dai paesaggi dell' erosione "normale", modellati dai corsi d'acqua.

Dal punto di vista morfodinamico le doline costituiscono delle unità idrografiche elementari, che con i loro sistemi di versanti convogliano l'acqua verso il fondo ove ha inizio una circolazione sotterranea.

Lo studio morfometrico di queste forme carsiche permette di affrontare l'analisi quantitativa dell' ambiente carsico. Il confronto fra i diversi parametri può fornire risultati inattesi e stimolare ipotesi sull' evoluzione e la dinamica di questo caratteristico "geoecosistema".

Vengono elencati ed illustrati tutti i principali parametri morfometrici delle doline e viene sviluppata una discussione preliminare sui metodi di analisi spaziale.

Si intende, con questo, sia fornire suggerimenti metodologici sulle fonti dei dati, i sistemi di misura, i parametri naturali meritevoli di considerazione, sia stimolare riflessioni sulle scelte di elaborazione delle variabili morfometriche e sul significato dell' analisi statistica e la correlazione fra diversi parametri.

Dopo una breve rassegna di alcune ricerche morfometriche del passato vengono presentati tre diversi esempi relativi ad aree carsiche delle Prealpi Venete (Cansiglio-Cavallo, Montello) e del Carso di Trieste.

Da questi esempi si coglie la complessità delle problematiche che emergono dall' analisi morfometrica, che non possono prescindere sia dalla qualità dei dati, sia dall' inquadramento geomorfologico e ambientale di ciscuna area.

\section{INTRODUCTION}

The morphometric analysis applied to karst environments enables a quantitative description of karst landforms and their distribution; a comparison of the various parametric values may give unexpected results and lead to new hypotheses.

The measurement of morphometric parameters, through field survey or 
over maps and aerial photographs, demands hard work and is time-consuming. Also mathematical-statistical treatment of the consequent data is rather complex. At present, this job is made much easier through computers and suitable software. The rapid development of Geographical Information Systems (G.I.S.) now constitutes a solid aid to morphometric analysis of landforms.

In beginning a morphometric analysis, the main problem is the lack of suitable maps with sufficient altimetric resolution; for this reason, altimetric parameters of dolines were very often neglected; on the other hand, planimetric attributes were mostly considered. Nevertheless, the relief is sometimes fundamental in comparing different kinds of karst, for example, tropical and temperate karst (FORD and WilLIAMS, 1989). Fortunately in many developed countries technical cartography on the scale 1:5,000 and 1:10,000 is available; it can show the relief sufficiently accurately for a detailed morphometric analysis.

Not all karst areas are suitable for a morphometric study which can be restricted by certain particular situations (for example, doline irregularity).

Morphometric analysis is possible under the following conditions:

a) the number of dolines must be high;

b) the dolines must lie over the same morphological unit; they cannot be distributed over different geological formations or in different topographical positions;

c) the dolines must not coalesce or be too irregular in shape.

Geometrical attributes of dolines are numerous. Some of them are currently employed in karst research and are used for the classification of dolines; a precise geomorphological significance has been attached to their values and ratios. Other parameters were less used either because of the measurement difficulties, or for problems of interpretation.

The goal of this work is to rearrange and, possibly, list in full all the geometrical attributes of dolines and to give a correct definition, both through studies found in literature, and by means of the first practical applications. Procedures for measurements on field, maps and aerial photographs of doline parameters are briefly mentioned.

Spatial analysis is only mentioned here; a study concerning this subject and its problems will be presented in a separate further paper. Morphometric investigations based on the parameters illustrated in this work will be done in order to define the morphological and genetic sense of each attribute. 


\section{AN OUTLINE OF THE CLASSIFICATION OF DOLINES}

The doline is the most specific form of karst landscape, which enables one to distinguish it from "normal" erosional landscapes shaped by surface water courses. In this sense it may also be considered a "diagnostic" form (FORD and WILLIAMS, 1989). It consists of an enclosed depression on a soluble solid rock, ranging widely in size, similar to a "crater" with one or more absorbing cavities in the bottom, generally covered by soil sediments or scree deposits, which permit underground drainage of water.

The dolines were first studied in the Classical Karst (Carso di Trieste) where their common planimetric shape is nearly circular, corresponding to a slope rupture between the plateau surface and the inner slopes of the hollow. The upper rim, or contour, which determines the perimeter, enables one to define the diameter of the doline, ranging from a few meters to more than one kilometre. Since in other karst areas the plan form is polygonal in shape and marks the upper rims of the slopes of adjacent dolines, it would be more correct to speak of axis or axes. The vertical dimension of a doline is called depth, which in nature ranges from a few decimetres to hundreds of meters.

From a morphodynamic point of view the dolines constitute elementary hydrographic units, comparable to the simplest basins, which, with their systems of slopes, convey water to a central point. In this way they constitute "point recharge depressions" (FoRD and WILLIAMS, 1989). Here the water is able to percolate inside the rock body, flowing into a system of underground channels to feed an aquifer reservoir or a spring. Hence a doline constitutes an initial morpho-functional-unit of a specific hydrographic system which develops mainly underground.

CVIJIC' (1893) first introduced the name of "doline" which means "small valley", to underline the analogy between this form and a small normal hydrographic basin. Nevertheless later authors proposed to change this name to a more specific one, like the "morpho-name" "vrtaca", or the new name of "kraska", to indicate the doline as the basic and diagnostic karst form (GAMs, 1973).

In the different treatises the classification of dolines is, in general, in accordance, with some variants in the definitions of the forms. On this subject we recommend the texts of GORTANI $(1908,1959)$, the thorough study of CRAMER (1941) and the more recent detailed discussions of SwEETING (1972) and MASsimi (1979). For some authors a doline is any enclosed basin in soluble rocks with the exception of those with extensive flat bottoms (polje). Among the large dolines, subtypes such as uvalas and cockpits have been distinguished. For other authors the dolines must fit inside a well-defined dimensional range. 
The attempts to classify the dolines are based on differing criteria, such as the following:

- the topographical and geometrical features,

- the genetic and evolutionary mechanisms,

- the topographical context,

- the morpho-climatic context,

- the hydrogeological characters and mechanisms.

The variance in the geometrical characters is linked with the inequalities of the perimeter, the slopes and the bottom. The perimeter may present a subcircular, elliptical, polygonal or also irregular shape; in the last case the basin may be of a composite form, deriving from the coalescence of more than one doline. The sides range from a slope of a few degrees to vertical, with differences even inside the same doline, which may be also strongly asymmetrical and/or dissymmetrical. The bottom may be punctiform, or may present varying sub-horizontal extensions, or may even be subdivided into different, distinct, nested depressions; sometimes the bottom may constitute the flat surface of a small lake.

The shapes of dolines are often schematised, so as to relate to three dimensional geometrical forms or to objects of everyday use. One of the main parameters considered in this context is the diameter/depth ratio $(\mathrm{D} / \mathrm{H}$ ratio: the inverse of $\left.\mathrm{RH} / \mathrm{D}_{[47]}\right)$. On the basis of this ratio many authors, starting with CVIJIC' (1893), have defined both the compared objects and the geometrical forms, as shown in the table.

\begin{tabular}{|c|c|c|}
\hline D/H ratio & similar objects & geometrical forms \\
\hline$D / H>5$ & plate & trunk of cone \\
\hline $5>D / H>2$ & bowl & hemisphere \\
\hline $2>D / H>1,5$ & funnel & cone \\
\hline $1,5>D / H$ & pit & cylinder \\
\hline
\end{tabular}

Obviously this systematic approach leads to imprecisions in the actual form. Indeed, with reference to the geometrical form, a doline may be conical or cylindrical in shape even if the depth is much less than the diameter. In addition, slopes with a concave profile, which should characterise the bowllike (or hemispheric) dolines, are not common; in fact plate-like dolines exist, but are explained either by the presence of thick filling deposits caused by non karstic processes, or by human modification.

In other classifications the following parameters are taken into consideration: 
- the maximum diameter/minor diameter ratio (DMAX ${ }_{[2]} / \operatorname{DMNR}_{[3]}$ ),

- the length axis/width axis ratio $\left(\mathrm{LAXI}_{[5]} / \mathrm{WAXI}_{[8]}\right)$,

- the width axis/depth ratio (WAXI [5] $_{\text {HMAX }}$ [37]) (see WHITE, 1988),

- the profile of the slopes,

- the planimetric size of the doline.

In the morphogenetical classification, in general, the following types of dolines are distinguished:

- normal solution dolines, formed by chemical solution of the rock; the water converges to a central absorbing area which becomes a zone of accelerated corrosion;

- alluvial or suffusion dolines, which form inside covers of unconsolidated rocks, like alluvial or till deposits, lying above karstifiable rocks; the development of "buried dolines" inside the soluble rocks, caused by infiltrating waters, causes subsidence and suffusion of the material above and the development of closed depressions;

- subsidence dolines, caused by gradual collapse of coherent, non-soluble, but permeable rocks (e.g.: sandstone) lying above karstifiable rocks; the water infiltrating along the fractures of the top rock reaches the soluble rock dissolving it; the effect is a differential subsidence of the non-soluble rock and the development of closed depressions;

- collapse dolines or depressions which develop because of the interference of an underground cavity and the topographical surface when the thin roof of a hole breaks down.

To these types could be added a type of "deep subsidence doline", more frequent above highly soluble rocks like salt; here the existence of deep cavities, where water is able to infiltrate may cause a progressive subsidence of the surface, sometimes with the development of small lakes; this type is also the consequence of the abandonment of salt mining tunnels.

With reference to the topographical context, the following types of dolines may be distinguished:

- valley bottom dolines;

- plateau dolines;

- slope dolines;

- uvala and polje bottom dolines;

- glacial cirque bottom dolines.

In a morpho-structural context the dolines may be distinguished both on the basis of the lithological type, the transitional location between different rocks, the attitude of the rocks, the positions along faults, etc.. So gypsum dolines, limestone dolines, marble dolines, marl dolines, dolines in sub-horizontal strata, dolines in strata $\mathrm{x}^{\circ}$ degrees inclined, fault line dolines, anticline or syncline axis dolines. 
In a morpho-climatic context it is possible to distinguish tropical karst dolines, temperate karst dolines, periglacial environment dolines, etc..

Regarding the hydrogeological features and processes, dolines formed by infiltration of surface run-off water (overland flow and soil waters), can be distinguished from those developing through concentrated infiltration starting from suspended aquifers inside intensely fissured relict zones, or with widespread high-porosity rock units, lying above less fissured rocks. The last-mentioned dolines develop in proximity to the lithological boundaries, where the water movement is changing from slow and diffused to fast and concentrated (SAURO, 1973, 1974). Williams (1985) outlined a hydrological model of doline evolution, presuming the influence of an "epikarstic zone", that is a zone just below the soil, characterised by an ephemeral aquifer resident inside the network of fissures, down to a few meters below the soil, enlarged by the karst processes. In this zone, different hydraulic conductivity develops in relation to the entity and speed of runoff, with accelerated dissolution in some sub-zones and in particular where a transition from a sub horizontal circulation to a nearly vertical one occurs.

Many of the dolines and closed depressions result from complex origins which are due not only to karst processes. For example the glacio-karstic depressions are the result of both karst and glacial processes, the swallowdolines of the blind valleys are the result of fluvial and karst processes. In general, most of the middle latitude dolines are the result also of periglacial processes, which influence slope evolution and accumulation on the bottom of soil sediments and debris.

Thus in an analysis of dolines it is necessary not to forget both the influence of lithology and structure, and the complex role played by the different morphogenetical processes.

\section{PARAMETERS QUOTED BY AUTHORS, THEIR DESCRIPTION AND MEANING}

\subsection{Measured parameters}

Listed hereunder are the geometric parameters of dolines, quoted by authors and partly integrated. It is possible to obtain almost all the parameters using large scale maps or aerial photos; it is possible also to measure them by direct survey in the field, but only in the case of some of them is measurement easy or possible in a reasonable period of time.

\subsubsection{Planimetric parameters}

All the following parameters consider the planimetric shape of a doline. 


\subsection{1.a. Linear planimetric parameters}

\section{[1] PLEN = perimeter length ( rim length, border length)}

Planimetric length of the curve that circumscribes the depression. It is distinguished by the locus of the points where the slope changes.

The definition is not suitable for all actual situations. This is above all the case for a slope gradually connecting with the internal slope of the doline, so that the slope variation is continuous (fig. 1).
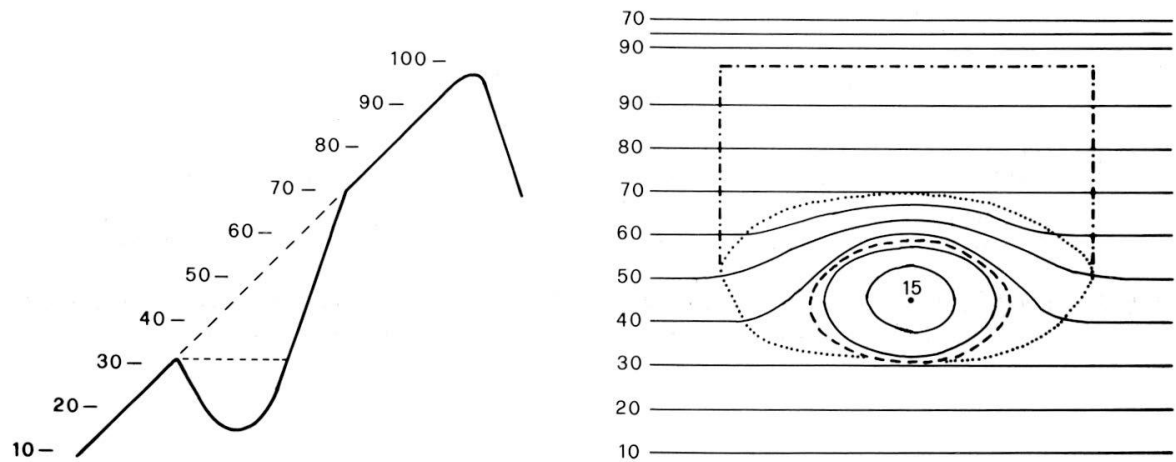

Fig. 1 - Vertical section and map of a doline on a regular slope. The dashed line (the easiest to be traced on the map) shows the perimeter of the closed depression; the dotted line closes the portion of the slope influenced by the doline; the dash and dot line marks the water divide. The problem of tracing the perimeter of a doline on a slope is always rather difficult, so if dolines of such a type are not frequent, it is better to leave them out of the examined population.

\section{[2] DMAX = Maximum diameter}

The segment linking the two most distant points of the perimeter.

\section{[3] DMNR = Minor diameter}

The longest segment linking two points of the diameter and perpendicular to the maximum diameter.

In circular dolines it is of the same length as the maximum diameter (fig. 2).

\section{[4] DMIN = Minimum diameter}

The shortest among the segments perpendicular to DMAX ${ }_{[1]}$ provided it is included between homologous segments of greater length.

If the curve showing the lengths of all the segments perpendicular to $D M A X_{[I]}$ has more than one maximum, DMIN ${ }_{[4]}$ is the segment corresponding to the principal minimum. The parameter is significant only in the case of irregular dolines and depressions of complex origin (fig. 3) 


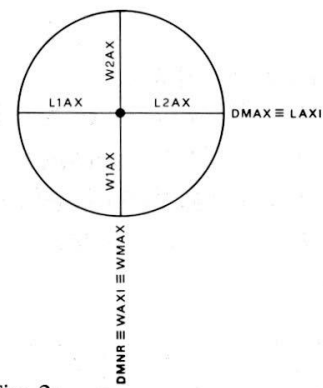

Fig. 2

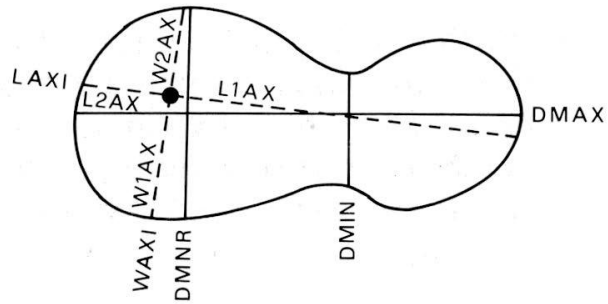

Fig. 3

Fig. 2 - Circular doline with a centered swallow.

$\operatorname{DMAX}_{[2]}=\mathrm{LAXI}_{[5]}=\mathrm{DMNR}_{[3]}=\mathrm{WAXI}_{[8]}=\mathrm{WMAX}_{[11]}=\mathrm{DAVE}_{[25]}=\mathrm{DIDE}_{[26]}$.

$\mathrm{L}_{1 \mathrm{AX}} \mathrm{A}_{[6]}=\mathrm{L}_{2 \mathrm{AX}}\left[\mathrm{f]}=\mathrm{W} 1 \mathrm{AX}[9]=\mathrm{W} 2 \mathrm{AX}_{[10]}\right.$

$\operatorname{ICIR}_{[41]}=\operatorname{RLEN}_{[43]}=\mathrm{RWID}_{[44]}=\mathrm{RL}_{[45]}=\operatorname{PSIM}_{[46]}=\operatorname{ISIN}_{[48]}=1 . \mathrm{RP} / \mathrm{R}_{[50]}=2 \pi$

Fig. 3 - On dolines with narrowings, the minimum diameter (DMIN $\left.{ }_{[4]}\right)$ can be traced. So shaped closed depressions usually derive from the coalescence of two previous dolines.

\section{[5] LAXI = Length axis, basin length}

The longest segment that has its extrema on the perimeter and crosses the lowest point of the depression.

In symmetric dolines with lowest point in the centre, the LAXI coincides with the DMAX ${ }_{[2]}$ (fig. 4).

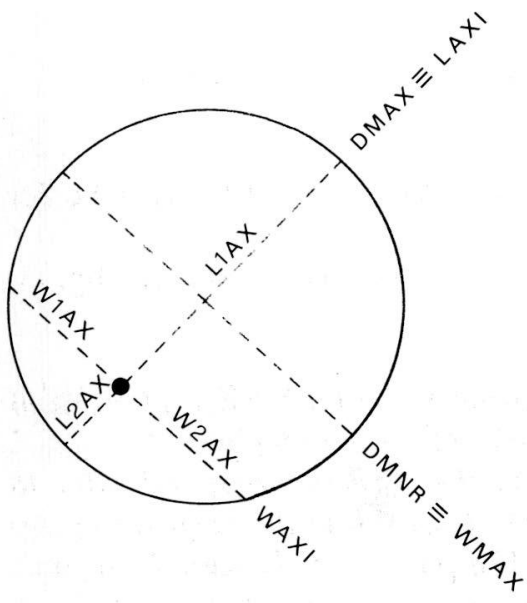

Fig. 4 - Circular doline with an eccentric swallow.

$\operatorname{DMAX}_{[2]}=\operatorname{LAXI}_{[5]}=\operatorname{DMNR}_{[3]}=\mathrm{WMAX}_{[11]}=$ $\operatorname{DAVE}_{[25]}=\operatorname{DIDE}_{[26]}$.

$\mathrm{W}_{1 \mathrm{AX}}[9]=\mathrm{W}_{[9]} \mathrm{AX}_{[10]} . \operatorname{ICIR}_{[41]}=\mathrm{RWID}_{[44]}=$ $\mathrm{RL} / \mathrm{W}_{[45]}=\operatorname{ISIN}_{[48]}=1$.

$\mathrm{RP} / \mathrm{R}_{[50]}=2 \pi$. 


\section{[6] L1AX = Main semiaxis of length}

The longer semiaxis of the $\mathrm{LAXI}_{[5]}$ divided at the lowest point of the depression.

\section{[7] L2AX = Minor semiaxis of length}

The shorter semiaxis of the $\mathrm{LAXI}_{[5]}$ divided at the lowest point of the depression.

[8] WAXI = Width axis

Segment perpendicular to the $\mathrm{LAXI}_{[5]}$, crossing the lowest point of the doline and having its extrema on the perimeter.

[9] W1AX = Main semiaxis of width

The longer semiaxis of the $\mathrm{WAXI}_{[8]}$ divided at the lowest point of the doline.

\section{[10] W2AX = Minor semiaxis of width}

The shorter semiaxis of the WAXI ${ }_{[8]}$ divided at the lowest point of the doline.

\section{[11] WMAX = Maximum width, basin width}

The longest segment linking two points of the perimeter, perpendicular to the $\mathrm{LAXI}_{[5]}$, but not necessarily crossing the deepest point of the depression (fig. 5).

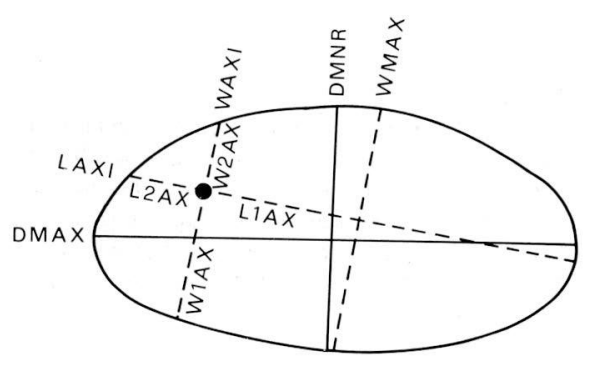

Fig. 5

Parameters of an elliptical doline with an eccentric deepest point.

\section{[12] AXIS = Axis}

The line with its extrema coinciding with those of the DMAX ${ }_{[2]}$, locus of the points that are the same distance from the two "arches" of the perimeter sliced by its two extrema.

The parameter is significant where dolines are asymmetric. It is difficult to outline it in an objective way: it has the characteristic of a descriptive geometric attribute. 


\subsection{1.b. Areal planimetric parameters}

\section{[13] ADOL = Area}

Measurement of the planimetric surface bordered by the perimeter.

\section{[14] ASUR = Axial surface}

The minimum surface bordered by the $\mathrm{LAXI}_{[5]}$ and the two lines of maximum dip which originate at the extremum of the $\mathrm{LAXI}_{[5]}$ and end at the deepest point of the doline.

\section{[15] ARUN = Area of internal runoff}

Planimetric surface of the watershed of the doline.

\subsection{1.c. Angular planimetric parameters}

\section{[16] DDIR = Maximum diameter direction}

The azimuth angle of the $\operatorname{DMAX}_{[2]}$ to the true North (from $0^{\circ}$ to $180^{\circ}$ ).

It may be correlated to structure or tectonics (fig. 6).

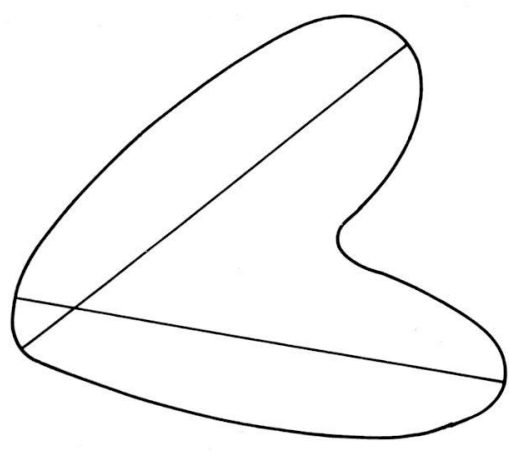

\section{Fig. 6}

Sometimes there is more than one direction in drawing the maximum diameter and the length axis. In the example of a heart-shaped doline the two lobes of the doline have the same importance and the two diameters have the same length; in such a case some directional parameters cannot be chosen.

\section{[17] FSEN $=$ Bottom sense}

Azimuth of the vector linking the highest point of the perimeter and the deepest point of the bottom (from $0^{\circ}$ to $360^{\circ}$ ).

By this parameter it is possible to establish if there is an influence on the shape of the doline by strike and dip of the rock layers or by the dip of the slope.

\section{[18] PSEN = Sense of the perimeter}

Azimuth of the vector linking the highest point of the perimeter to its lowest point (from $0^{\circ}$ to $360^{\circ}$ ). 
[19] LSEN = Length axis sense

Azimuth of the centripetal vector coincident with the $\mathrm{L}_{1 \mathrm{AX}} \mathrm{Cb}_{\text {(from }} 0^{\circ}$ to $360^{\circ}$ ) (fig. 7).

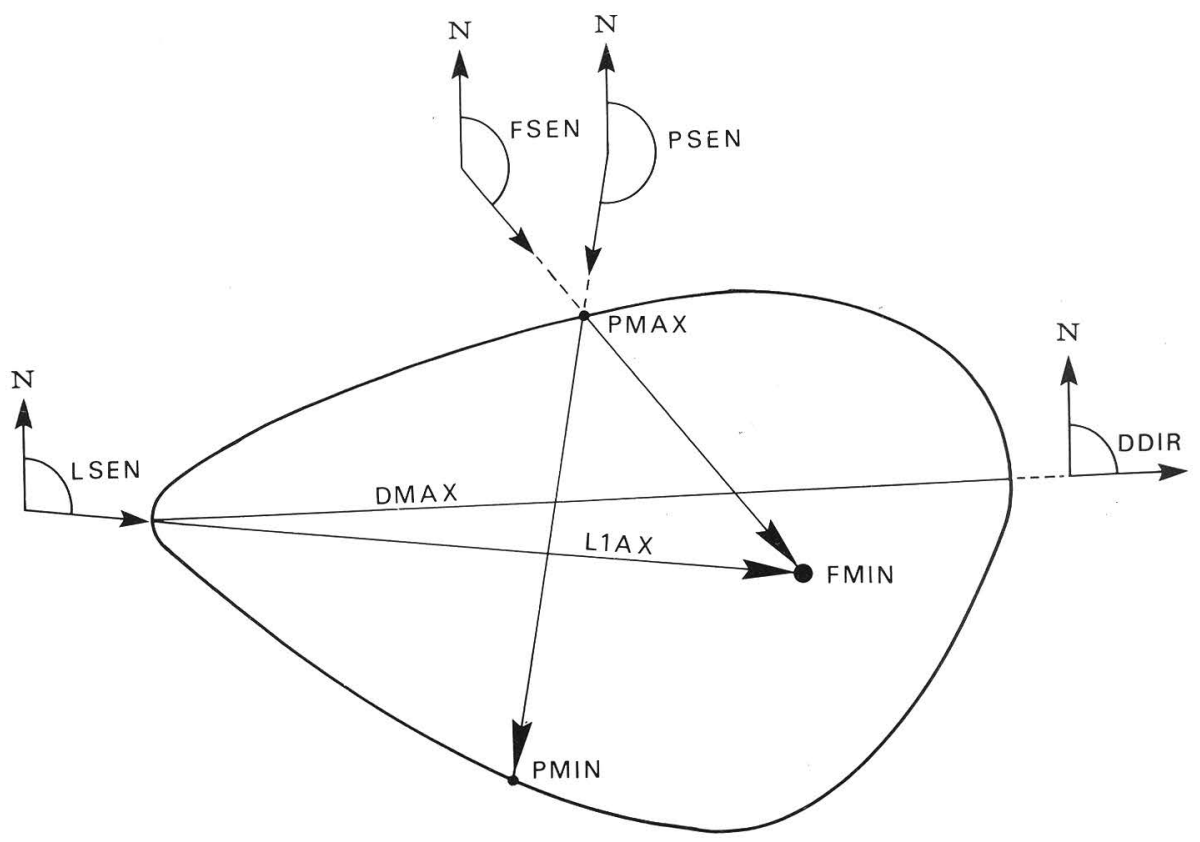

Fig. 7 - Directional parameters of a doline.

\subsubsection{Altimetric parameters}

[20] PMAX = Maximum altitude of the perimeter

Altitude of the highest point of the perimeter.

[21] PMIN = Minimum altitude of the perimeter

Altitude of the lowest point of the perimeter.

[22] FMIN = Minimum altitude of the doline bottom

Altitude of the lowest point of the doline.

[23] F2AL, F3AL, ... = Secondary, tertiary, ... altitude of the bottom

Altitude of the lowest point of every closed depression inside a doline. It is used in complex forms. 
[24] PDEN = Total difference in elevation of the perimeter

Summation of all the differences in height along the perimeter.

In the same way the total difference in elevation of the divide can be defined. The parameter is applied only to great depressions.

It is evident that it is not possible to measure all the listed parameters in every doline, either because a very large scale map is not available, or a direct survey in the field is not possible; usually in common topographic maps the doline form is somewhat simplified.

Often it is difficult to define the elements of the doline to measure. A clear example is the case of a doline on a slope: although more than one reasonable way of tracing the perimeter has been proposed, in every case a solution is chosen by the researcher (fig. 1); in such situations, if dolines of that type are a minimum part of the whole population, they could be left out; if there are many uncertain forms, it is important that the measurement of the parameters is done in a homogeneous way by a single researcher. The researcher must also indicate the chosen criteria of data collection.

\subsection{Computed parameters}

Parameters listed in the former section have a significance either indipendently or in connection with each other. The possible correlations between the parameters are too numerous, so we tried to point out just the significant ones. Moreover some parameters are not directly measured, but computed (volume, area, ...). Some other parameters are more significant than the measured parameters used to calculate them; for instance, that is true for $\mathrm{RH} / \mathrm{D}_{[47]}$ : a ratio of depth to average diameter.

\subsubsection{Planimetric parameters}

\section{[25] DAVE = Average diameter}

Arithmetical average of DMAX $[2]$ and $\mathrm{DMNR}_{[3] \text {. }}$

If the dolines have a very irregular border, the DAVE can be computed as the average of $D M A X_{[2]}, D M N R_{[3]}$ and the two diameters crossing at $45^{\circ}$.

\section{[26] DIDE = Ideal diameter}

Measurement of the diameter of the circle with area equivalent to the planimetric surface of the doline.

\section{[27] CEQU = Equivalent circumference}

Circumference of the circle with area equivalent to the planimetric surface of the doline. 


$$
\mathrm{CEQU}=\pi\left(\mathrm{DIDE}_{[26]}\right)
$$

[28] CCIR = Circumference of the circle circumscribed to the perimeter

\subsubsection{Angular parameters}

[29] SAVE = Average dip slope along a section

The vertical angle of the segment linking a point on the perimeter and the deepest point in the depression.

This is, in fact, the actual dip of the slope in a conical doline. If the doline has a horizontal bottom, the parameter is found from the segment linking a point on the perimeter with the nearest point on the rim of the flat bottom.

[30] L1AN = L1AX angle

Vertical angle of the segment linking the extremum of the semiaxis $\mathrm{L} 1 \mathrm{AX} \mathrm{X}_{[6]}$ on the perimeter and the deepest point in the doline.

\section{[31] $\mathrm{L} 2 \mathrm{AN}=\mathrm{L} 2 \mathrm{AX}$ angle}

Vertical angle of the segment linking the extremum of the semiaxis $\mathrm{L} 2 \mathrm{AX}_{[7]}$ on the perimeter and the deepest point in the doline.

\section{[32] W1AN = W1AX angle}

Vertical angle of the segment linking the extremum of the semiaxis $\mathrm{W} 1 \mathrm{AX}_{[9]}$ on the perimeter and the deepest point in the doline.

\section{[33] W2AN = W2AX angle}

Vertical angle of the segment linking the extremum of the semiaxis $\mathrm{W} 2 \mathrm{AX}_{[10]}$ on the perimeter and the deepest point in the doline.

In conical dolines the four latter parameters reflect the real dip of the slope. In dolines with concave or irregular bottoms, the computed angle does not reflect the true dip, but it is necessary to calculate the concavity index ICON $[34]$.

\section{[34] ICON = Concavity index}

Arithmetical average of the four vertical angles of the length and width semiaxes.

$$
\mathrm{ICON}=\frac{\left(\mathrm{L} 1 \mathrm{AN}_{[30]}+\mathrm{L}_{2 \mathrm{AN}}[31]+\mathrm{W} 1 \mathrm{AN}_{[32]}+\mathrm{W} 2 \mathrm{AN}_{[33]}\right)}{4}
$$


[35] DSAV = Doline average dip slope

It is computed for the whole slope of the depression, or it is calculated between nearby contours.

Dip between two contours

$$
\text { DSAV }=\frac{\left(\mathrm{C}_{1}+\mathrm{C}_{2}\right) \cdot \mathrm{I}}{2 \mathrm{~A}_{\mathrm{i}}}
$$

Average dip of the closed depression:

$$
\operatorname{DSAV}=\frac{\left(\frac{1}{2} \mathrm{C}_{0}+\mathrm{C}_{1}+\ldots+\mathrm{C}_{\mathrm{n}-1}+\frac{1}{2} \mathrm{C}_{\mathrm{n}}\right) \cdot \mathrm{HDOL}_{[38]}}{\mathrm{n} \cdot \mathrm{ADOL}_{[13]}}
$$

$C_{n}=$ length of the contours

$n=$ number of contours

$I=$ difference in altitude

$H D O L_{[38]}=$ maximum depth

$A D O L_{[13]}=$ planimetric surface of the doline

$A_{i}=$ planimetric surface closed by two contours

\subsubsection{Altimetric parameters}

\section{[36] HPER = Perimeter depth}

Difference in altitude between the highest and the lowest point of the perimeter.

[37] HMAX = maximum depth

Difference in height between the maximum altitude of the perimeter and the lowest point of the depression.

[38] HDOL = doline depth, closed depression depth

Difference in height between the minimum altitude of the perimeter and the lowest point of the depression.

\section{[39] HBAS = basin depth}

Difference in height between the maximum altitude of the water divide (or inside the area of doline internal runoff) and the lowest point of the depression. 
[40] HVOL = volumetric depth

Doline volume / planimetric area ratio.

\subsubsection{Dimensionless parameters}

[41] ICIR = circularity index

Ratio between the circumference of the circumscribed circle and the planimetric doline perimeter.

[42] VDVP = volume development

Ratio between the volume of the doline and the volume of a cone with a base equivalent to the planimetric doline area and the height equivalent to the maximum depth.

This ratio is approximately 1 when the doline is almost conical; it is lower than 1 when the doline slopes are convex; the opposite is true when the doline slopes are concave: the ratio is then greater than 1. The same procedure is applied to the flat bottom dolines assimilated to a truncate cone.

[43] RLEN = length ratio

$$
\operatorname{RLEN}=\frac{\operatorname{L1AX}[6]}{\operatorname{L2AX}[7]}
$$

[44] RWID = width ratio

$$
\mathrm{RWID}=\frac{\mathrm{W} 1 \mathrm{AX}[9]}{\mathrm{W}^{2 \mathrm{AX}}[10]}
$$

Both RLEN $[43]$ and RWID depend on the eccentricity of doline lowest point.

[45] $\mathrm{RL} / \mathrm{W}=$ length/maximum width ratio, elongation ratio

$$
\mathrm{RL} / \mathrm{W}=\frac{\operatorname{LAXI}_{[5]}}{\operatorname{WMAX}_{[11]}}
$$

This is an index of planimetric doline shape; it gives information about perimeter symmetry (unlike PSIM $[46]$ which is an internal symmetry index).

When $R L / W=1$, the shape is equidimensional. 
[46] PSIM = product of symmetry

$$
\operatorname{PSIM}=\mathrm{RLEN}_{[43]} \cdot \mathrm{RWID}_{[44]}
$$

This is an index of internal symmetry of the depression swallow; if the swallow is perfectly centered, PSIM $=1$, otherwise it increases (fig. 8).

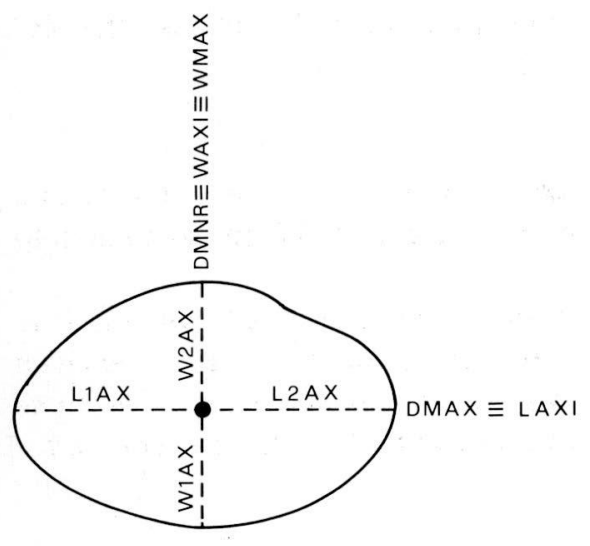

Fig. 8

Elliptical doline with a centered swallow. $\mathrm{L}_{1 \mathrm{AX}} \mathrm{X}_{[6]}=\mathrm{L}_{2} \mathrm{AX} X_{[7]}$ and $\mathrm{W} 1 \mathrm{AX} X_{[9]}=\mathrm{W} 2 \mathrm{AX}[10]$. $\operatorname{RLEN}_{[43]}=\operatorname{RWID}_{[44]}=\operatorname{PSIM}_{[46]}=1$.

\section{[47] $\mathrm{RH} / \mathrm{D}=$ depth/average diameter ratio, cross-section ratio}

It is an internal shape index. It can help in genesis research: for example, a solution doline field has similar RHID values; if a collapse doline field is considered, RHID values show a broad distribution.

$$
\mathrm{RH} / \mathrm{D}=\frac{\operatorname{HMAX}_{[37]}}{\mathrm{DAVE}_{[11]}}
$$

[48] ISIN = sinuosity index

Ratio between the planimetric perimeter length of doline and the circumference of a circle with area equivalent to the planimetric area of the doline.

This ratio, which is never less than 1 , is an index of irregularity of the doline border and elongation of the doline itself. As a matter of fact, in the case of an elliptical shape, the doline is not irregular, but ISIN is greater than 1 .

[49] IENC = enclosure index

$$
\text { PSIM }=\text { RLEN }_{[43]} \cdot \text { RWID }_{[44]}
$$


[50] $\mathbf{R P} / \mathbf{R}=$ perimeter/ideal radius ratio

Ratio between the perimeter length and the radius of a circle with area equivalent to the doline area.

\section{[51] IART = articulation index}

Ratio between the summation of absolute values of difference in height measured along the perimeter and the maximum depth.

$$
\operatorname{IART}=\frac{\operatorname{PDEN}_{[24]}}{\operatorname{HMAX}_{[37]}}
$$

[52] IARR = relative articulation index

Ratio between the summation of absolute values of difference in height measured along the perimeter and the perimeter length.

$$
\mathrm{IARR}=\frac{\operatorname{PDEN}_{[24]}}{\operatorname{PLEN}_{[1]}}
$$

\subsection{Other parameters}

\section{[53] VOLU = volume}

The Simpson formula is used to measure the volume of a doline; the volume is computed adding all the truncated cones with a base corresponding to the surfaces enclosed by the subsequent contour lines representing the doline and, as height, the contour interval. The deepest part of the doline (if it is a cone doline) is considered equivalent to a cone with a base represented by the area circumscribed by the lowest contour line and, as height, the difference in altitude between the lowest contour and the bottom. This method is applicable to dolines well represented by contour lines. The less the contour interval, the more the doline regularity and the sharper the volume measurement.

Computation of volume is difficult and can be done only for very big dolines, using good maps, or, in the presence of very regular dolines which fould be considered as regular geometric solids.

\section{[54] CHYP = relative hypsographic curves}

These represent the cumulative distribution of doline area against the depths of the depression. The two variables are presented as percentages related to their maximum value.

[55] ODEP = depression order

Highest hierarchical order of streams which drain to the swallow. 


\section{QUANTITATIVE PARAMETERS OF A MORPHOKARST UNIT}

Only some of the parameters referring to the morphokarst unit are hereby listed; they are those used for the definition of doline parameters.

\subsection{Parameters of a karst area}

[56] KMAX = maximum altitude of a karst area

[57] KLEN = maximum length of a karst area

[58] KMIN = minimum altitude of a karst area

[59] KARE = total surface of a karst area

\subsection{Quantitative parameters of a field of dolines}

[60] DNUM = total number of dolines

[61] DDEN = depression density

$$
\mathrm{DDEN}=\frac{\mathrm{DNUM}_{[60]}}{\mathrm{KARE}_{[59]}}
$$

[62] IPIT = index of pitting

$$
\mathrm{IPIT}=\frac{\mathrm{KARE}_{[59]}}{\sum_{\mathrm{i}=1}^{\sum_{\mathrm{DNUM}} \mathrm{ADO}[13]}}
$$

[63] APER = percentage area of hydrographic basin occupied by enclosed depressions

$$
\begin{aligned}
& \mathrm{i}=\mathrm{DNUM}[60] \\
& \sum \text { ADOL[13] } \\
& \mathrm{APER}=\frac{\mathrm{i}=1}{\mathrm{KARE}_{[59]}} \cdot 100
\end{aligned}
$$

In polygonal karst $A P E R=100$ 
[64] $\mathrm{RDOL}=$ doline area ratio

$$
\mathrm{RDOL}=\frac{\mathrm{APER}[63]}{100}
$$

This is the reverse of the index of pitting (IPIT $\left.{ }_{[62]}\right)$; in polygonal karst it is equivalent to 1 .

[65] KRUN = summation of areas of internal runoff of dolines

$$
\operatorname{KRUN}=\sum_{\mathrm{i}=1}^{\mathrm{i}=\operatorname{DNUM}[60]}
$$

LIST OF PARAMETERS IN NUMERICAL ORDER

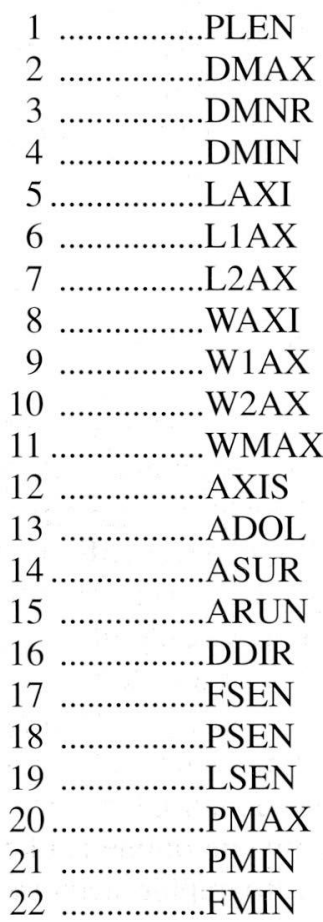

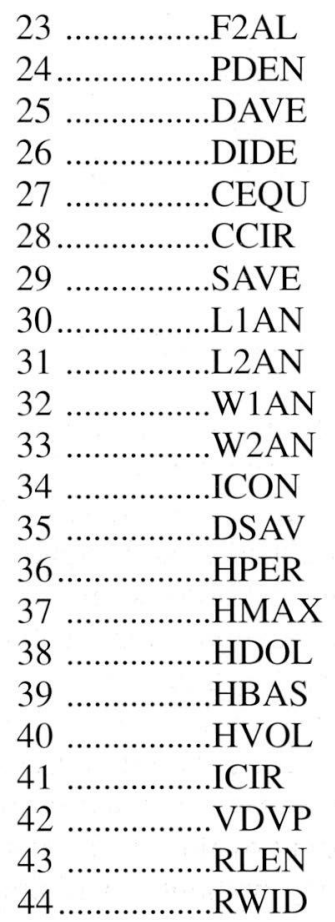

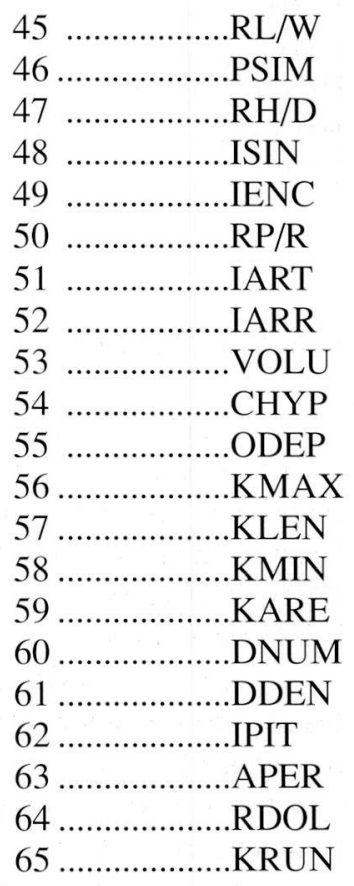




\section{LIST OF PARAMETERS IN ALPHABETICAL ORDER}

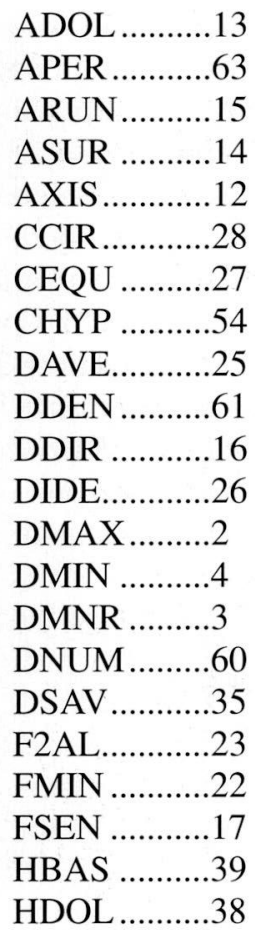

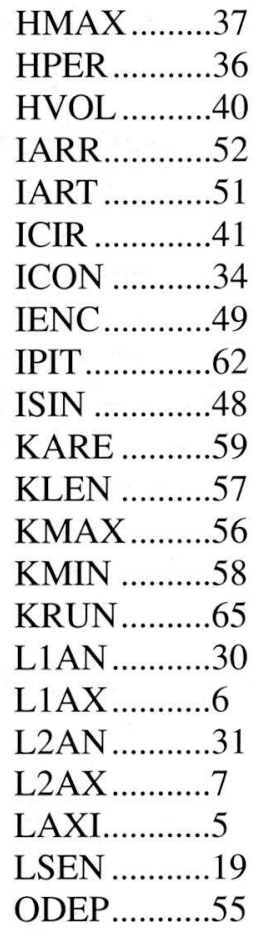

\begin{tabular}{|c|}
\hline DEN ................24 \\
\hline PLEN .... \\
\hline PMAX... \\
\hline PMIN ....... \\
\hline PSIM ....... \\
\hline PSEN ..............18 \\
\hline RDOL …….......64 \\
\hline RH/D ................47 \\
\hline RL/W ...... \\
\hline RLEN ................43 \\
\hline RP/R ……............. \\
\hline RWID ....... \\
\hline SAVE \\
\hline VDVP …..........42 \\
\hline VOLU …..........53 \\
\hline W1AN ................ \\
\hline W1AX …........... \\
\hline W2AN................ \\
\hline W2AX ............10 \\
\hline WAXI.............. \\
\hline WMAX ..........11 \\
\hline
\end{tabular}

\section{SOME REFLECTIONS ON THE SPATIAL ANALYSIS}

When an observer is studying a karst area on a topographical map or from a summit on the field, at first he detects the forms together rather than individual aspects. This operation constitutes a "spatial lecture" or even a "spatial analysis". A mathematically based spatial analysis requires different types of operations which are beyond the aims of this paper. Nevertheless a brief introduction to some applications of spatial analysis may be helpful.

Here the spatial analysis of "normal" cone-shaped solution dolines is taken into consideration. Each solution doline must be considered in its geomorphological context. In fact the solution doline represents the main elementary form, which marks a spot of accelerated corrosion inside complex threedimensional surfaces in constant evolution. To examine only one doline is like analysing just one small valley without examining the hydrographic network 
of which this is a part. In fact each different geomorphological factor plays a unitary role, even if of different intensity, in the total karst morpho-unit.

The first step of the spatial examination is to establish whether the dolines are isolated forms inside a karst surface or whether they are contiguous forms. In the first case their planimetrical shape will be circular or elliptical and their rims will correspond to slope breaks inside the same surface. However, in the second case the circular forms will no longer be possible and will be substituted by regular or irregular polygonal shapes, representing both the ridges or crest lines and, at the same time, the water divides between adjacent depressions. While in the first case we have surfaces with scattered "spot dolines", where the dolines occupy only a certain percentage of the whole surface, in the second we will find surfaces completely covered by "alveolar celldolines", similar to the honeycomb of bees or an egg-box, where the dolines cover the total surface (honeycomb karst and/or polygonal karst). It is also possible to find intermediate situations where both spot dolines and groups of dolines are partially in contact with each other.

In a honeycomb or polygonal karst the alveolar cells are the result of the interference of the upper parts of the reverse cones: the virtual circles, which should represent the enlargement of the border of the dolines, if no touching dolines exist, interfere with the "circles" of the adjacent dolines with a consequent dismantling of the interposed relief and a lowering of the perimeters proportionately as great as the overlapping of the circles. Consequently, in the perimeters, saddles alternated with summits will develop.

If the dolines enlarge at the same rate, the number of sides of the polygons will depend on the form of the net based on the bottom points of the basins: if the central points of the cones form a net with square meshes, the resulting polygons will be quadrangular. If the net is less regular (e.g. rhomboidal) or dolines or alignments of dolines develop at different rates, the resulting polygons will be polygonal with more sides, often with different lengths (fig. 9).

Pioneer of the spatial analysis of karst basins is WiLliams (1971, 1972a, $1972 \mathrm{~b}$ ). Despite some criticisms on some mathematical procedures, more recent papers (GRAY, 1974; VINCENT, 1987) have confirmed the results of WILLIAMS.

In the spatial analysis, besides the examination of the plan forms of the doline perimeters, the distribution of the lowest points of each doline is important. These points represent the "foci" of accelerated corrosion and therefore are comparable to the "talwegs" (or valley bottoms) of a fluvial pattern, which represent lines of accelerated erosion.

With reference to these points or, rather, to each closed basin, when a net of small dry valleys is recognisable inside it, WILLIAMs has applied the evalua- 

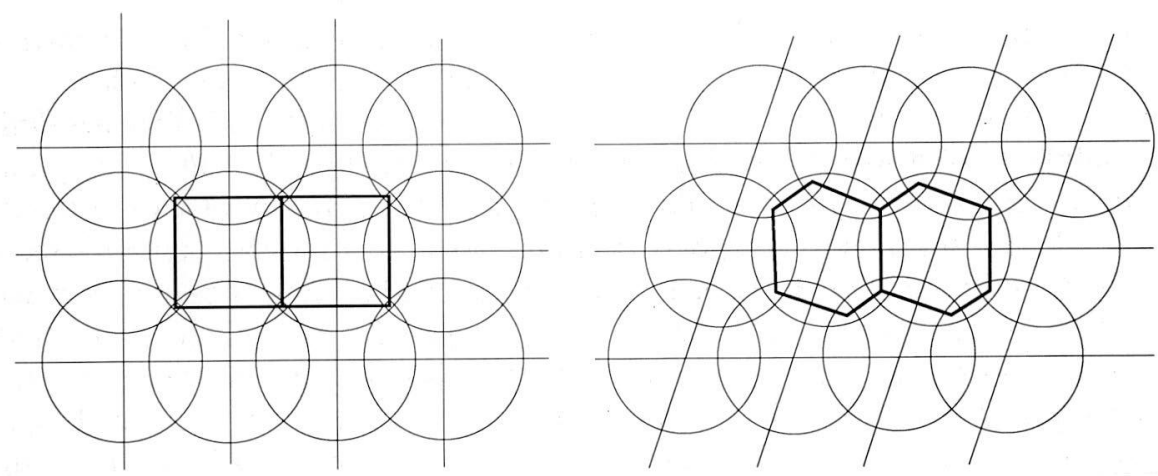

Fig. 9 - In a honeycomb or polygonal karst the alveolar cells are the result of the interference of the upper parts of the reverse cones representing the first funnel shaped dolines.

When the borders of these dolines come into contact a process of dismantling of the interposed ridges begins. The lowering of the perimeters is proportionately as great as the overlapping of the circles. Consequently, in the perimeters, saddles alternated with summits will develop.

If the dolines enlarge at the same rate, the number of sides of the polygons will depend on the form of the net based on the bottom points of the basins: if the central points of the cones form a net with square meshes, the resulting polygons will be quadrangular. If the net is less regular (e.g. rhomboidal) or dolines or alignments of dolines develop at different rates, the resulting polygons will be polygonal with more sides, often with different lengths.

tion of hydrographic order of STRAHLER $(1957,1975)$, based on the segment of highest hierarchy.

Taking into consideration the bidimensional distribution of points, as single dolines in small scale maps or as lowest points of dolines in a honeycomb karst, it is possible to define the dispersion patterns and their intensity and grain. Common types of dispersion are those which are regular or uniform, random or casual, and clustered, fine, medium and coarse grained, reticulate with different patterns and density.

It is opportune to remember that when one considers the dolines in their topographical context, a karst unit is examined in its totality; on the other hand, if one examines only the barycenters or the lowest points of the dolines, only adimensional aspects are taken into consideration.

One type of plan or bidimensional analysis often utilised is that of the "nearest neighbour" formulated, from a mathematical point of view, by CLARK and Evans (1954). These two authors attempted to find an index based on the formula $R=L a / L e$, where $L a$ is the average actual distance between points in a spatial distribution and $L e$ is the average expected distance if the points were randomly disposed. $L e$ will be equal to $\frac{1}{2} \sqrt{\mathrm{D}}$ where $D$ is the point density. 
This type of analysis may give interesting indications in order to compare different populations and to estimate the reciprocal influence between contiguous dolines; in the case of the latter it is also important to take into consideration other dimensional parameters like the diameter and the depth.

We quote just a few of the possible three dimension analyses:

- definition of the degree of articulation or roughness of the topographical surface based on the dispersion and strength of the vectors;

- multispectral analyses of the relief based on local relief energy;

- estimation of the isopaches of the karst relief.

The definition of the degree of articulation of the topographical surface, based on orientation, dispersion and strength of vectors, has been explained and applied by DAY (1979). As a first step it is necessary to sample the elevations on a square net with sides selected on the base of the relief type. Drawing the diagonals of the squares, a net of isosceles right-angle triangles is obtained, where, taking into consideration the three elevations of the vertexes, it is possible to detect, in the centre of each triangle, a vector perpendicular to the surface. If the topographical surface is nearly flat the vectors will show sub-parallel orientations and the sum of the vectors of a selected unitary area will give a resultant vector of high strength; however, if the topographical surface is rough the vectors will show high dispersion and the resulting vector of the corresponding unitary area will be of low strength. The terrain roughness $(K)$ is defined by $K \sqrt{=}(N-1) /(N-R l)$, where $N$ is the number of triangles inside the unitary area and $R l$ is the strength of the vector resulting from the sum of the single vectors.

BROOK and Mitchelson (1981) applied a new analytical procedure to a cockpit karst area of Porto Rico. They applied single and double Fourier analysis to a series of values sampled along both E-W and N-S segments, the intersections of the meshes of a selected net overlapping the map, and to the random points of the bottoms of the basins and the main summits. In this way the most significant "wave length" of that type of karst relief have been achieved.

We suggest a very similar "Relief Multispectral Analysis". In this method the ratios RR/SS are evaluated, where RR is a relative relief value inside a square of a series of nets overlapping the map, each net with a mesh side reduced to half the previous one, and SS is the side length of the corresponding square mesh. Computing the ratios in a diagram it is possible to estimate the degree of articulation or roughness of the karst relief. In fig. 10 only one horizontal dimension has been taken into consideration; apart from this, the values of the larger nets are insufficient to give a representative spectrum; in any case it is possible to recognize as the most significant band the one where there is both an increase of the mean value, in comparison with the previous one, and a reduction of value dispersion. In the example the diagnostic band is that of $125 \mathrm{~m}$. 


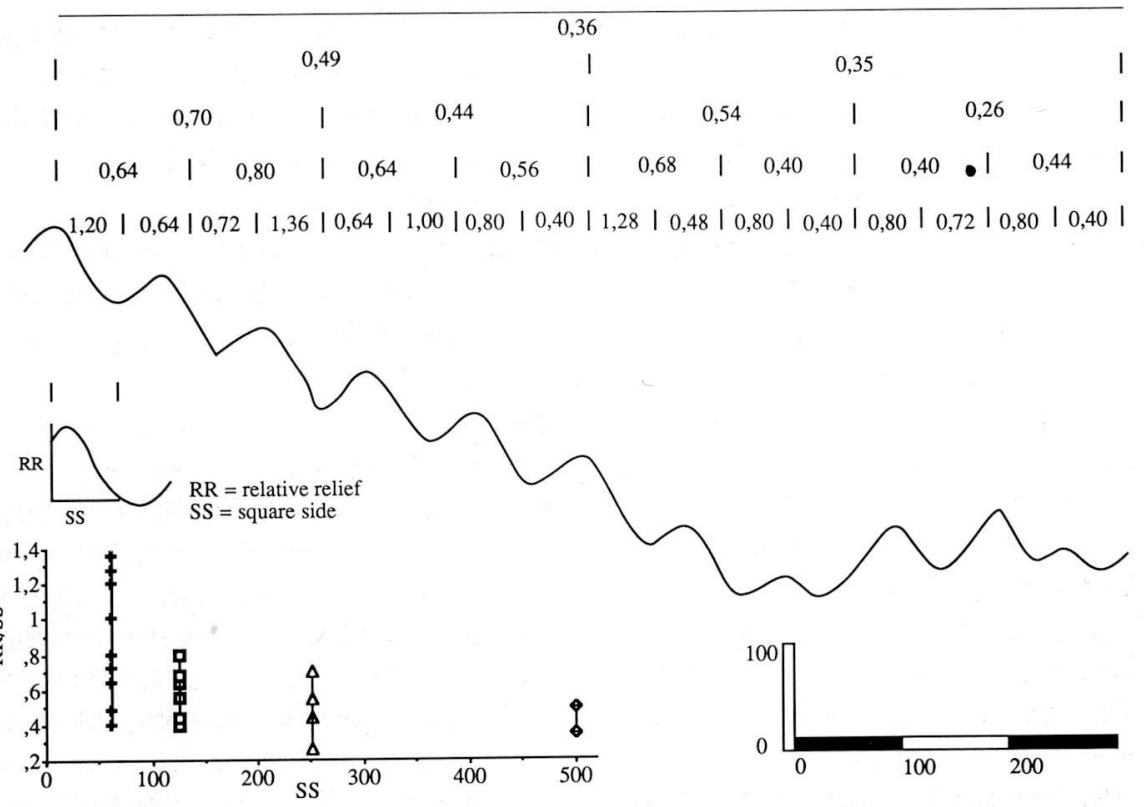

Fig. 10 - The design illustrates a method of «Relief Multispectral Analysis». In this method the ratios $\mathrm{RR} / \mathrm{SS}$ are evaluated, where RR is a relative relief value inside a square of a series of nets overlapping the map, each net with a mesh side reduced to half the previous one, and SS is the side length of the corresponding square mesh. Computing the ratios in a diagram like the one on the lower left, it is possible to estimate the degree of articulation or roughness of the karst relief. In the figure only one horizontal dimension has been taken into consideration; besides, the values of the larger nets are not sufficient to give a representative spectrum; in any case, it is possible to recognize the most significant band as that where there is both an increase of mean value, in comparison with the previous one, and a reduction of value dispersion. In the example the diagnostic band is that of $125 \mathrm{~m}$.

Another type of three dimensional analysis of a polygonal karst relief could start from detection of the lowest points and the highest points of the perimeter of each karst basin. If these two points are connected, it is possible to assign to the central point of each segment the corresponding value of difference in elevation. It is possible to draw an isolines map based on the values of these points, which represents the "isopaches" of the karst relief.

A field of spatial analysis worthy of research and investigation is that of "orientation" and "vectors" derived not only from individual morphometric parameters inside a population of dolines as axes, but also from the alignments and in general the vectorial interrelations between two or more forms. This is an extremely promising field, worthy of study in the future. 


\section{ASPECTS OF THE STATISTICAL ANALYSES}

The objective of this chapter is not to introduce the methods of statistical analyses (for which specific treatises exist), nor to give an overview of the research work developed in this field by different authors (for this please see the synthesis in the handbooks of CHORLEY, 1972, JenNings 1985, White, 1988, FORD and WILLIAMS, 1989), but merely to develop certain reflections on the choices of possible processing of morphometrical variables and the significance of the correlation between different parameters.

Firstly it is important to remember that all the information obtainable from topographic maps, aerophotographs and field survey must be considered. Qualitative information derived from "spatial perception" of karst relief may help in the choices of the most significant quantitative analyses. With this we do not mean that classic statistical analyses are not worth applying. These analyses may sometimes give unexpected and, in some aspects, surprising results. In any case for a correct interpretation of such results the karst researcher must not forget the complex geological, geomorphological and environmental context.

The following forms may be compared:

- forms which are the result of the same morphogenetical process (thus it is incorrect to compare solution dolines with collapse dolines);

- assemblages of forms which constitute homogeneous, or not too heterogeneous populations; if from the maps it is possible to distinguish further populations, based on one or more characters, linked with geological, geomorphological, topographical and climatic factors, it is opportune firstly to examine each population separately and only then to compare them.

So if from a morphometrical analysis it is possible to define the statistically significant "typical form" inside a population of dolines, the peculiar characteristics of this form must be considered within the geological, geomorphological, climatic, pedological, vegetational context of the karst area. This helps one to understand the role of the different factors in influencing the geomorphological development.

Each type of doline must be compared with the more common reference forms, which can be deduced from basic evolution models, such as:

- the cone-doline and the derived truncated cone forms, or saucer-like, hemispherical, bowl-like, etc.., when the basins are isolated;

- the form of the alveolar cells, when the depressions constitute a honeycomb or polygonal karst.

With reference to a conical form the two more significant parameters are the average diameter $\left(\mathrm{DAVE}_{[25]}\right)$ and the depth $\left(\mathrm{HMAX}_{[37]}\right)$ if the dolines are developed on a sub-horizontal surface. 
For the alveolar cells the axes between the summits (vertexes of the polygonal cell), the axes between the saddles (distances from points approximately in the middle of opposite sides of a polygonal cell) and the differences in elevation summit-bottom and saddle-bottom must be taken into consideration. To analyse other characteristics of the polygonal cells it is also important to consider the number of sides, the product of symmetry, etc.

Inside a population of forms and its most representative "morpho-type" the deviations from the reference forms and models should be considered; among these, the slope asymmetry and dissymmetry, the lengthening of one diameter or axis, etc.. Some of these aspects are also to be seen in the topographical map and may be worthy of quantitative analysis. As examples, we remember the directions of lengthening influenced by the geological structure, which are often also associated with alignment of dolines with the same orientation.

The following are some of the more significant variables which may be correlated:

- the linear planimetric parameters among them such as the main and minor diameters $\left(\mathrm{DMAX}_{[2]}, \mathrm{DMNR}_{[3]}\right)$;

- the linear planimetric parameters with vertical parameters, such as the average diameter $\left(\mathrm{DAVE}_{[25]}\right)$ and the depth $\left(\operatorname{HMAX}_{[37]}\right)$;

- the areal planimetric parameters with vertical parameters, such as the surface $\left(\mathrm{ADOL}_{[13]}\right)$ and the depth $\left(\operatorname{HMAX}_{[37]}\right)$;

- the linear planimetric and the vertical parameters in relation to the areal planimetric parameters and the volumetric parameters;

Each parameter of morphodynamic significance, as the hydrographic order of the basin, may be correlated with morphometrical parameters (FORD and Williams, 1989).

Also parameters of environmental significance such as elevation, soil type, vegetation habitat or climatic type may show some correlation with certain morphometrical parameters.

Often some problems may be found in the analyses of:

- transitional forms between cone-dolines, alveolar cells, basins deriving from a reorganisation of a previous drainage network by karstification;

- contiguous forms apparently similar but originating from different processes (normal solution dolines and old collapse dolines which are now evolving as solution dolines);

- populations of composite and complex forms which cannot be compared with the neighbouring normal dolines, such as the "multiple" dolines with lobate perimeter and more than one bottom, the dolines nested inside larger depressions as uvalas, the dolines originating from the karstification of a drainage network. 
Sometimes the complexity of the karst relief may be linked to the "superimposing" of several populations and generations of landforms. If so, it is important to analyse separately each distinguishable population and generation, to understand the evolutionary sequence of the morphological evolution.

To explain these forms it is also important to consider the morphological situation inside the regional evolution. For example the existence of a fluviokarstic network, alternated with areas with dolines, could be the result of the influence of a pre-existing hydrographic network in the cover-rocks, partly inherited from the soluble underlying rocks. In this way, perhaps, some areas with a higher density of dolines in the Carso di Trieste could be explained.

One limit of the karst morphometry is that the topographical form of the depressions does not correspond, as a rule, to the forms in soluble rock, since the basins act as traps for sediments, e.g. soil sediments, rock particles, wind transported silt coming both from the slopes and from the outer surfaces. Excavations and geophysical prospections have shown that filling deposits, even some tens of meters thick, occupy some dolines. Sometimes a former doline is filled up to the rim and only the part above is now an open hollow; these forms have been called "open dolines" (MAGALDI and SAURO, 1982).

For all these anomalous forms the morphometrical studies must be introduced with a description based on the topographical map and need detailed geomorphological field research.

\section{SOME PREVIOUS MORPHOMETRIC STUDIES AND RESULTS}

Some morphometric studies made in the past by specialists are presented and discussed to understand how the subject was tackled and what kind of results the research gave.

The first application of morphometric studies to karst phenomena dates to the XIX Century with CVIJIC' (1893) and is followed at the beginning of this century by LOZINSKI (1907) up to the work of CRAMER (1941).

In Italy, the first systematic application belongs to SEGRE (1948), in which many morphometric parameters of dolines are listed, even though some of them are only approximately defined. The author found a connection between the attributes and the tectonics of the studied area, the lithological characteristics of karstifiable formations and the general topography of the doline field.

Among the karstologists who faced the matter of doline genesis recognization, we must mention COLEMAN and BALCHIN (1959) who, through a morphometric study of the Mendip Plateau, attempted to reconstruct the evo- 
lution of the dolines. Plotting the depression depth against the diameter, they obtained a series of scattered points. This simple result allowed them to confirm a gravitational collapse genesis; otherwise, in the case of the solution doline, owing to the tendency towards dynamic equilibrium, all the points were expected to be aligned over a straight line (constant depth/diameter ratio).

WiLliAMs (1966) first published a work on karst morphometry from medium scale maps and aerial photographs. He developed a method of morphometric analysis of temperate karst landforms of the British Isles, adopting the techniques evolved for fluvial morphometry to provide measurements of all important karst features. The chosen parameters dealt with karst, fluvialkarst and hydrogeological features of the Ingleborough District. The results of the study seemed to confirm a relationship between fluvial morphometry and swallow system in karst areas, in accordance with the laws of morphometry. WILLIAMS also found the fundamental parameters for the description of temperate karst landscapes.

HOWARD (1968) compared in his study: (a) the presence of doline bottoms over a certain stratigraphic layer and the thickness of the calcareous bench in which dolines formed; (b) the frequency of relief summits corresponding to the strata; (c) the difference between the number of doline perimeters and bottoms lying over each level. This research established the correlations of frequency and depth of dolines with rock facies.

JENNINGS (1975) made his study in New Zealand assuming that morphometry is a tool of effectiveness in morphogenesis studies. He obtained his data from land surveys of doline attributes. Measurements were made with low precision, taking into account length, width and average depth of dolines (in effect, he considered DMAX $\mathrm{DMA}_{[2]}=\mathrm{LAXI}_{[5]}$ e $\mathrm{DMNR}_{[3]}=\mathrm{WMAX}_{[11]}=$ $\left.\mathrm{WAXI}_{[8]}\right)$. He demonstrated that statistical analysis of doline shapes and dimensions produces a better knowledge of a karst area, than a few scattered detailed works; with this method, reconstruction of doline genesis is also possible. The results can support or contrast with the conclusions made through a classical approach to the problem.

DAY (1983) made a study of the morphology and development of dolines in Barbados; the area under survey was $124.5 \mathrm{~km}^{2}$. He studied the dolines on a statistical basis taking as a sample the population of dolines inside $1 \mathrm{~km}^{2}$ square. Inside each square cell, he measured the doline density. Then, the research was done on 7 main parameters:

1) local relief, measured on the map as the difference between the highest and the lowest point inside the square cell;

2) local slope gradient, measured on the map;

3) valley density, as a permeability index (the more the valleys, the 
fewer the dolines and vice versa; the more the valleys and the lower the permeability;

4) valley order, computed in accordance with Strahler's method inside each square;

5) the distance to the nearest valley, expressed as the distance from the center of the square to the nearest valley;

6) soil depth, from literature and field surveys. The soil can increase chemical dissolution caused by water retention or chemical agent discharge;

7) water table depth.

All data were ordered in classes of altitude. The author also made the measurements of length, width, direction of maximum diameter (DDIR ${ }_{[16]}$, $\mathrm{RL} / \mathrm{W}_{[45]}$ and $\left.\mathrm{RH} / \mathrm{D}_{[47]}\right)$.

An accurate examination of results enabled verification of the existence of a spatial influence of doline development. The doline density seemed to vary according to the altitude; the dolines appeared clustered and influenced by structure along alignments. Two subpopulations were identified, the former in the interfluvials, the latter in the valleys.

Meneghel (Agnesi et al., 1989) made a morphometric analysis on gypsum karst of S. Ninfa (Sicily, Italy). The study dealt with closed depressions and hydrographic catchments with statistical analysis of the results. The measurements were made from topographic maps at a scale of 1:5,000 and involved the main morphometric parameters. An attempt was made to consider the reliability of the parameters on a statistical base and to find correlations among them.

In 1991 BABOÇı et al. published a paper on the surface karst morphology of an Apulian zone. The authors examined the spatial distribution of dolines and the length and azimuth of their diameters. A different doline density according to altitude and the influence of both regional tectonics and relief evolution was shown.

BARANY-KeVEI and MEzosi (1991) made a quantitative investigation on more than 80 dolines in the Aggtelek and Bükk Mountains (northern Hungary). They calculated more than ten parameters referring to the single doline or to the whole doline area. Some of the parameters are linked with tectonics, others to expositional and microclimatic factors. Particularly interesting is the asymmetry parameter referring to the direction of the cardinal points. 


\section{DATA SOURCES AND PRACTICE OF MEASUREMENT. TOPOGRAPHIC MAPS, AERIAL PHOTOGRAPHS, SURVEY IN THE FIELD}

\subsection{Data sources}

The parameters to be used in a morphometric study of dolines can be obtained:

a) directly by topographic measurement in the field;

b) indirectly by measurement on aerial photographs observed under a stereoscope or on large scale topographic maps. Images taken by satellite remote sensing now have spatial resolution of insufficient accuracy to be used in such a study.

\subsection{Measurements in the field}

Measurement of parameters directly in the field enable one to obtain accurate data. It is, however, time-consuming, so the studied area is limited by the available material, economic and human resources. For this reason, it is necessary to carefully limit the number of measurements and to use simple instruments to speed up the work.

The precision in measurements obtained with good topographic instruments is, on the other hand, too great in comparison with the uncertain identification on the ground of the elements of the doline in reference to the surveyed parameters.

Instruments to be used are different both concerning the dimension of the doline and its vegetation. In most situations the instruments used in a fast topographic survey (measurement tape, "topofil", optical telemeter, electronic longimeter, compass, clinometer, Abney's level, precision altimeter) are sufficient to measure morphometric parameters. However, as well as precision, the use of more sophisticated instruments (tacheometer, theodolite, geodimeter, G.P.S.) can make the measurement operations faster.

A sophisticated means of survey useful both for a better classification and a morphmetrical analysis is that proposed by SuSTERIC (1986), consisting of a field survey method based on tachymetery. Starting from a theodolite fixed in the lowest point of a doline, six radial profiles in a regular star pattern are traced. Along each profile twelve equidistant spot heights are evaluated. The relative coordinates of these 72 spot heights enable calculation, with a reasonable accuracy, of the real form of the doline and deduction, by means of computer processing, of all the main morphometric parameters. This method is surely one of the best ever proposed, but it is arduous and time consuming (the author estimates one and half hour for each non-forested medium size doline). So it is not suitable for large groups of dolines. 


\subsection{Measurements on aerial photographs}

On aerial photographs dolines are highly evident forms, also because of the vertical exaggeration observed by the researcher. Morphometric analysis done by photo-interpretation on large scale aerial photos is practical and sufficiently accurate, at least for some parameters.

A further advantage is the possibility to obtain good and similar results even using photographs which are very different in scale (Williams, 1971, 1972a). Interpretation could however be difficult because of vegetation and shadows on the ground.

To show the surveyed morphology clearly, it is common to draw on a transparent sheet, overlapping the photo, whilst it is being observed in the stereoscope. Usually the following are drawn: water divides, perimeters of dolines, swallows, tops of hills and towers, the complete hydrography (also minor and isolated creeks), the small valleys leading to the swallows. The maps which are drawn are later reduced to the requested scale.

One great limitation in the use of aerial photos (also vertical ones) is both the deformation introduced by relief displacement and the time-consuming work in getting good altitude values. The deformation is negligible in the center of the photo, but increases towards the rim, reaching values, depending on the geometric characteristics of the camera used, of displacement of the doline bottom that are of the same order of the depth of the doline itself. That displacement could make investigation by aerial photographs unsuitable where the precise position is required of some points in comparison with others at different altitude.

\subsection{Measurements on topographic maps}

Usually even large scale maps with small contour intervals cannot show the dolines in sufficient detail, especially if small and shallow; DAY (1983) establishes a limit of $5 \mathrm{~m}$ diameter. If the contour interval is greater than $10 \mathrm{~m}$, or the scale is smaller than 1:25,000, results obtained are rough and less meaningful. In order to make morphometric analysis good quality topographic maps are necessary, with a scale not less than 1:15,000 and contour intervals not larger than $10 \mathrm{~m}$.

One greater element of uncertainty in the use of maps is in tracing the doline perimeter. When the surface with dolines has a weak slope (karst plateau is the most common case) the perimeter is usually drawn around the outer closed contour (fig. 11), trying to cross the points where a slope change is believed to be. If the internal slopes of the doline are quite steep in comparison with the general surface, tracing the perimeter is easy, otherwise there is great uncertainty. It is more difficult when dolines are situated on a steep slope (fig. 1): downslope the position of the perimeter is clear; upslope, if there is no 
sharp change in gradient from the general slope to the internal slope of the doline, tracing the perimeter becomes subjective.

The lowest point of the doline is often determined by a spot height. If there is no indication, as in the case of truncate conical dolines, the altitude of the bottom is below the altitude of the lowest contour of the doline, by no more than a contour interval. In such a situation, however, it is impossible to determine the position of the deepest point to which many parameters are linked (fig. 12).

Usually in such a case the best way to make a morphometric analysis is to use large scale topographic maps, integrated with observation of aerial photographs, at a scale ranging from 1:5,000 to 1:25,000, to obtain information on altimetry. It is always useful to make a check in the field to complete the collection of data.

If the study area is too large, and it is impossible to measure the whole population of dolines, an analysis on sample is necessary, taking care in choosing samples representative in number and extent.

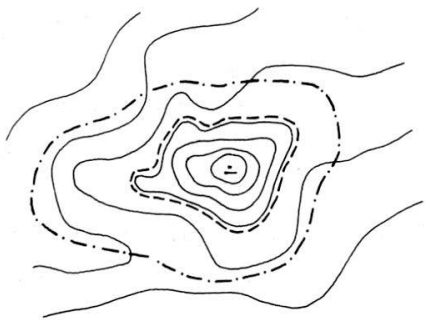

Fig. 11
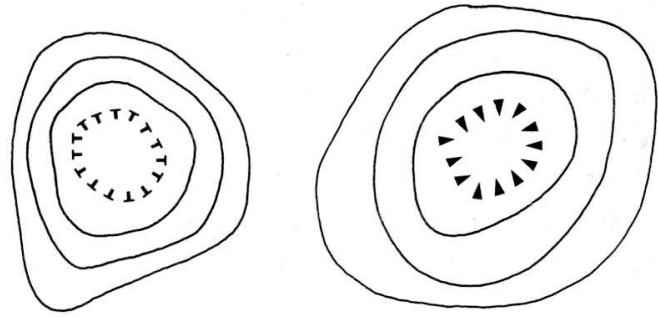

Fig. 12

Fig. 11 - Two options in drawing the doline perimeter on a map: the dashed perimeter embraces the highest closed contour, the dot and dash line was drawn considering the area morphologically influenced by the doline. The difference in dimension and shape of the two perimeters and of all the related parameters is clear.

Fig. 12 - Sometimes the flat bottom of a doline can be detected on the map (and also measured) using the symbols of dry masonry wall or of small escarpment.

\section{CASE HISTORIES}

Morphometric analysis over three different karst areas in Northern Italy is presented (fig. 13). They are just examples and are not exended over the entire karst morpho-unit. The case is different in the geomorphological context, karst style and the number of examined dolines. 


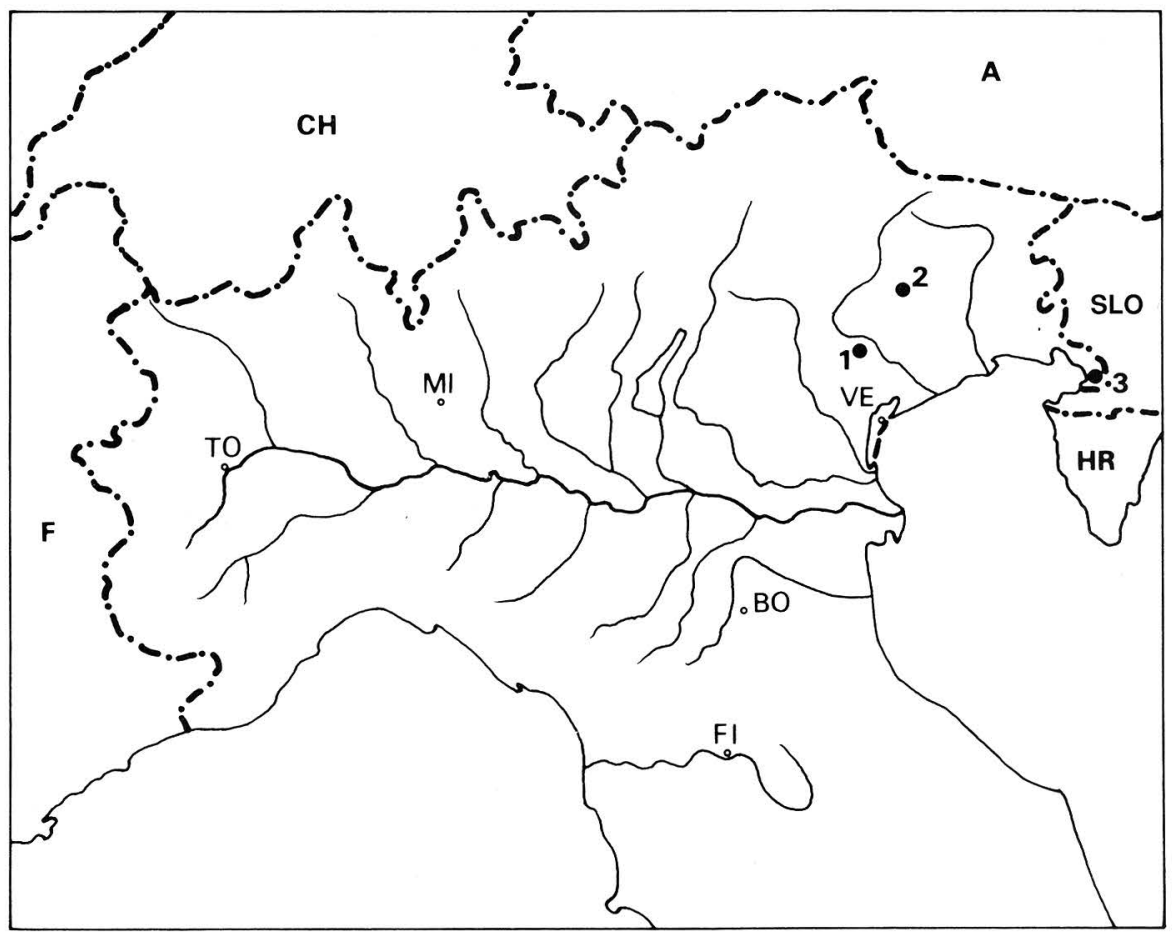

Fig. 13 - Location of the studied areas: 1) Montello; 2) Candaglia Plateau; 3) Carso di Trieste.

These three studies were made in order to verify the possibility of measuring the morphometric parameters presented before. An attempt to standardize the analyses was made adopting the same map types and methods. The maps are of a scale 1:5,000 and belong to the Regional Technical Map of the Veneto Region and the Friuli - Venezia Giulia Region. They are good black and white maps, derived from aerial surveys, not older than 10 years, with a contour interval of $5 \mathrm{~m}$.

No photo interpretation was made. The measurements were all done manually; the surfaces were measured by a planimeter, the curved lines by a simple curvimeter. In this phase, no C.A.D. was utilised.

There are a lot of more complex methods and tools to obtain more precise measurements, but they require special (and expensive) machinery, advanced know-how or they are time-consuming. We decided to propose the morphometric analysis in a simple way to give greater possibility of research to more scientists.

A quantitive description of the dolines is presented, but no interpretation 
of results - apart from some comments - has been made. The interpretation of the importance, value and applications of parameters will be the subject of a further publication.

\subsection{Montello}

Il Montello (the name means "little mount") is a broad hill elliptical in shape, located in the high Venetian Plain. It is $13 \mathrm{~km}$ long in a WSW-ENE direction and $5 \mathrm{~km}$ wide in a NNW-SSE direction; it covers a surface area of about $56 \mathrm{~km}^{2}$. The hill stands isolated in the plain, being separated from other hills by the Piave River on the east side and by a previous channel of the same river on the west side. On the northern side the Piave River flows in a broad valley, while on the southern side the alluvial fans of the Venetian plain open towards the Gulf of Venice. The Montello altitude ranges from 150 to $200 \mathrm{~m}$ a.s.l. for the main part, the maximum height being $371 \mathrm{~m}$ a.s.l.. The rocks forming the hill are a poligenic conglomerate, where most clasts are carbonatic, and levels of sandstones and shales. They are arranged in a broad anticline, as a result of a still active overthrusting in a SSE direction.

In the western part of the Montello there are 6 or 7 terraces (SACCARDO, 1885) explained by STELLA (1902) and Toniolo (1907) as fluvial terraces carved by the Piave River in the outcropping rocks whilst Montello was uplifting. MietTo and SAURo (1989) show that the older (the higher in altitude) the terrace, the greater the area of the terrace occupied by dolines. The remaining part of Montello is characterized by several karstic forms such as: dolines, uvalas, karstic valleys, blind valleys and reculées.

The hypogeum karst is well developed, and until now about 70 caves have been explored; the main cave, Busa di Castel Sotterra, was surveyed for nearly $6 \mathrm{~km}$.

The area chosen for the morphometric study of dolines is represented in a map issued by the cartographic office of the Regione del Veneto (Carta Tecnica Regionale, Elemento n ${ }^{\circ} 084142$, "Sacello") on a scale of 1:5,000, and is positioned NW of the village of Giavera. It is limited by the meridians of longitude $12^{\circ} 07^{\prime} 30^{\prime \prime} \mathrm{E}$ and $12^{\circ} 10^{\prime} 00^{\prime \prime} \mathrm{E}$ and by the parallels of latitude $45^{\circ}$ $48^{\prime} 00^{\prime \prime} \mathrm{N}$ and $45^{\circ} 49^{\prime} 30^{\prime \prime} \mathrm{N}$.

The investigated zone has a surface of about $6.5 \mathrm{~km}^{2}$, its maximum altitude is $310 \mathrm{~m}$ a.s.l., the minimum is $150 \mathrm{~m}$; the density of dolines (DDEN [61]) is 31 per $\mathrm{km}^{2}$. Dolines are particularly crowded in the northern sector, where the density is of 36 dolines per $\mathrm{km}^{2}$, becoming less frequent to the $\mathrm{S}$, where some small fluvial valleys are present at the rim of the Montello hill. The doline surface covers a large part of the whole territory, which is similar to a honeycomb karst; since the perimeters of the dolines are rarely in contact, this is not strictly true (fig. 14). 


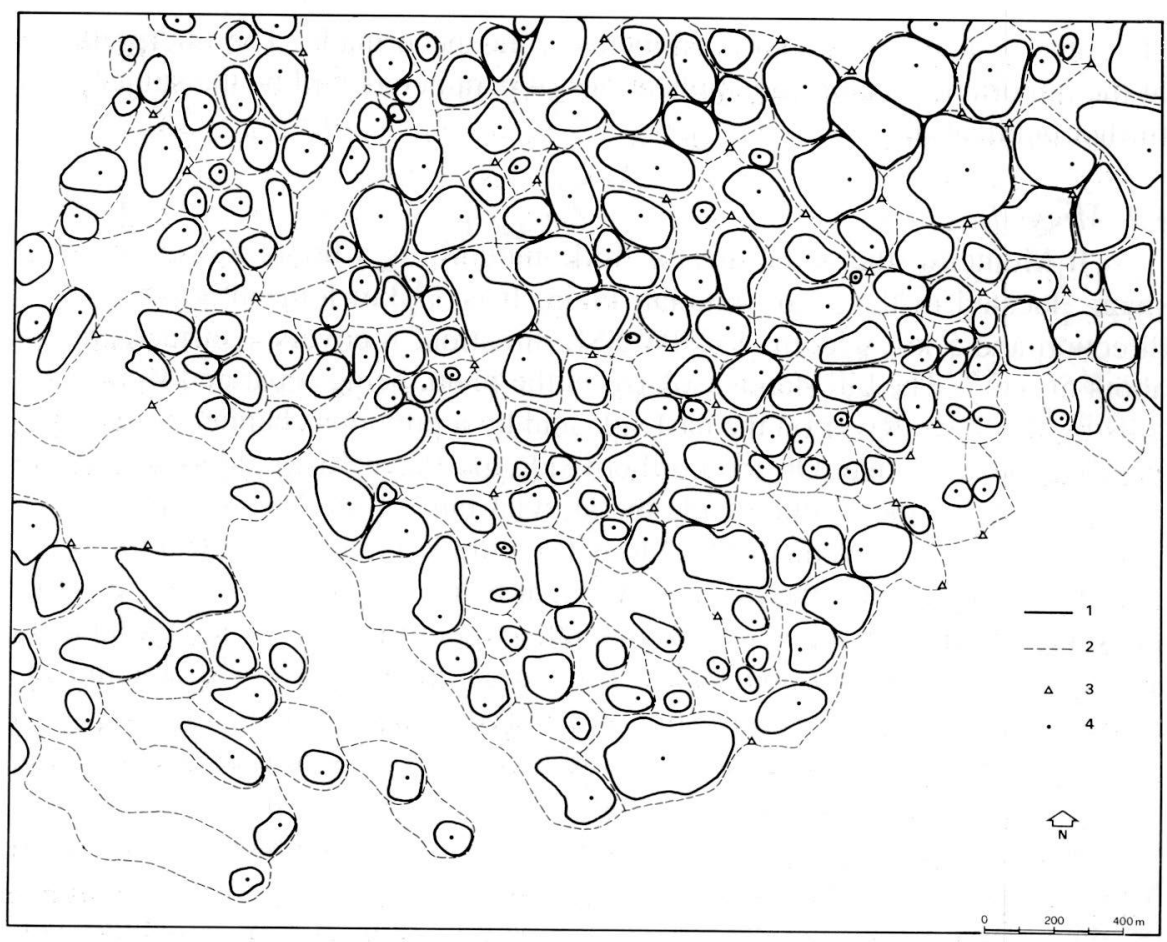

Fig. 14 - Sketch map showing the doline distribution in the studied zone of the Montello, the water divides and their tops. 1) doline perimeter; 2) water divide; 3) summits; 4) doline deepest point.

The obtained parameters of the 201 measured dolines are shown in table I. The doline bottom altitude $\left(\mathrm{FMIN}_{[22]}\right)$ ranges from $152 \mathrm{~m}$ to $287 \mathrm{~m}$ a.s.1., showing a regular distribution in accordance with the general plateau topography of the Montello. The maximum diameter $\left(\right.$ DMAX $\left._{[2]}\right)$ ranges from $32 \mathrm{~m}$ to $371 \mathrm{~m}$ with an average value of $143 \mathrm{~m}$ and a median of $130 \mathrm{~m}$; the frequency shows positive asymmetry demonstrated by the fact that the modal class is between $75 \mathrm{~m}$ and $100 \mathrm{~m}$. In more than $90 \%$ of the dolines the maximum diameter and the length axis $\left(\mathrm{LAXI}_{[5]}\right)$ coincide. For this doline population FERRARESE and MENEGHel (1992) have compared the direction of maximum diameter (DMAX $[2]$ ), with tectonic directions measured by CUCCHI (1978) in some caves; they found a slight correlation between the two. The depth/diameter ratio $\left(\mathrm{RH} / \mathrm{D}_{[47]}\right)$ is somewhat correlated with the origin and the evolution of the doline; Montello dolines have an average value of 0.15 , with a symmetrical distribution of the values around that central figure. According to the classification reported in Chapter 1, the dolines should result as saucer-shaped dolines. 
The elongation of the doline is expressed by the parameter $\mathrm{RL} / \mathrm{W}_{[45]}$, which is 1 for an equidimensional doline and the more it exceeds 1 , the more the doline is elongated. In the Montello area the average is 1.36, with standard deviation 0.28 . So dolines result as slightly elongated.

$\operatorname{PSIM}_{[46]}$ shows the eccentricity of the lowest point of the doline: the Montello values range from 1.04 to 9.73 , with an average value of 2.41 : Montello dolines show notable eccentricity.

In order to understand, also, the spatial relationship in the distribution of the dolines, an analysis with the method of the nearest neighbor as proposed by CLARK and EVANS (1954) has been carried out. A value of $R=1.266$ has been obtained, showing a significant tendency to a uniform distribution of dolines.

\subsection{Candaglia Plateau}

The studied area belongs to the Venetian Prealps along the edge of the Po-Venetian plain, and reaches an altitude of $1,356 \mathrm{~m}$ a.s.l.. It is a karst plateau in the middle of the Cansiglio-Cavallo Massif, which from a geological point of view belongs to the Southern Alps and represents the extreme southwestern end of the Carnic Alps.

The outcropping formations belong to reef limestone, very pure, of middle-upper Cretaceous; they have different facies and are mainly massive limestone, in thick benches, mostly fossiliferous (Rudistids). The general layering is not clear, but strata seem to have a general immersion towards NW and low inclinations (about $10^{\circ}-20^{\circ}$ ).

As a consequence of the limestone pureness of the Candaglia Plateau, the epigean karst landforms are well developed.

The chosen sample area is a small part of the plateau which is found on the SE sector of the Carta Tecnica Regionale of Veneto Region, Elemento n064103, "Pian delle Fontane".

The doline field has an irregular shape; it is elongated for about $2 \mathrm{~km}$ from $\mathrm{N}$ to $\mathrm{S}$ and the same from $\mathrm{E}$ to $\mathrm{W}$; the total area is $1.74 \mathrm{~km}^{2}$.

The southern and eastern border is the map frame, while on the other sides, the boundary is represented by the slope edge which borders the plateau and descend gradually to the Pian Cansiglio polje.

The studied area is limited by the meridians of longitude $12^{\circ} 26^{\prime} 00^{\prime \prime} \mathrm{E}$ and $12^{\circ} 27^{\prime} 00^{\prime \prime} \mathrm{E}$ and by the parallels of latitude $46^{\circ} 03^{\prime} 00^{\prime \prime} \mathrm{N}$ and $46^{\circ} 04^{\prime} 00^{\prime \prime} \mathrm{N}$.

The parameters referring to the morphokarst unit examined are presented on table I. Inside the studied sector the maximum elevation $\left(\operatorname{KMAX}_{[56])}\right)$ is $1,356 \mathrm{~m}$ and the minimum elevation $\left(\mathrm{KMIN}_{[58]}\right)$ is $1,232 \mathrm{~m}$.

90 dolines $\left(\mathrm{DNUM}_{[60]}\right)$ were measured with a depression density (DDEN $[61]$ ) equivalent to 51 dolines $/ \mathrm{km}^{2}$. The wide Candaglia depression was 
excluded from analysis because its form differs from other considered dolines. It is the large elongated uvala resembling in some characteristics a small polje that can be found in the central part of the map in fig. 15.

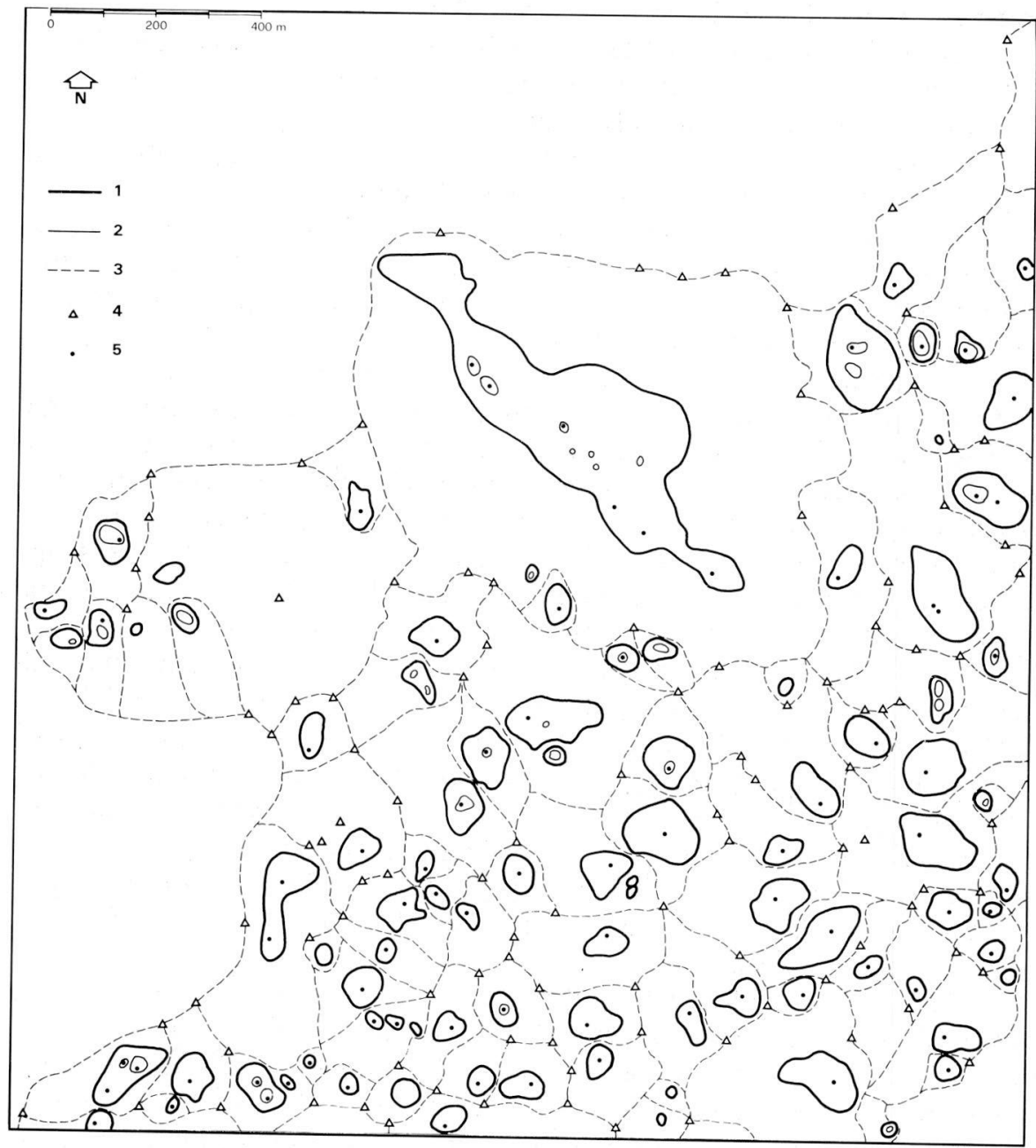

Fig. 15 - Sketch map showing the doline distribution in the studied zone of the Candaglia Plateau, the water divides and their tops. 1) doline perimeter; 2) doline bottom perimeter; 3) water divide; 4) summit; 5) doline deepest point.

The index of pitting (IPIT 62$]$ is equivalent to 4.86 and the percentage area occupied by dolines $\left(\mathrm{APER}_{[63]}\right)$ is $20.6 \%$ (this value is hardly significant because it was calculated on a small part of the basin, chosen at random). 
The karst depressions of the Candaglia plateau are generally well distinct and contiguous. For this reason, and being the limits of the studied area arbitrary, the sum of areas of internal runoff is equivalent to the total surface of karst area $\left(\mathrm{KRUN}_{[65]}=\mathrm{KARE}_{[59]}=1.74 \mathrm{~km}^{2}\right)$

The doline area ratio $\left(\mathrm{RDOL}_{[64]}\right)$ is 0.21 ; in any case, if we consider the catchment area of dolines against the total surface area of karst, then RDOL [64] $=1$, which is the value of the polygonal karst.

Average diameters of dolines range from $15 \mathrm{~m}$ to $170 \mathrm{~m}\left(\mathrm{DAVE}_{[25]}=65\right.$ $\mathrm{m})$ and dolines are often cone-like with open swallow.

The arrangement of dolines shows a certain regularity with some alignments linked to faults and fracture zones. The morphology of dolines is often influenced by tectonics which is the main factor affecting the planimetric shape and the cross section of dolines (CASTIGLIONI, 1964).

The average value of minor diameter $\left(\mathrm{DMNR}_{[3]}\right)$ is $53 \mathrm{~m}$, while that of maximum diameter $\left(\mathrm{DMAX}_{[2]}\right)$ is $78 \mathrm{~m}$, practically equivalent to the length axis $\left(\mathrm{LAXI}_{[5]}=79 \mathrm{~m}\right)$. Neither differences between width axis and basin width seem to be important $\left(\mathrm{WAXI}_{[8]}=52 \mathrm{~m}\right.$; $\left.\mathrm{WMAX}_{[11]}=53 \mathrm{~m}\right)$. This first result seems to indicate that a distinction between the two is redundant; maybe just one length parameter and one width parameter are sufficient for the shape description of a doline. The minimum diameter $\left(\mathrm{DMIN}_{[4]}\right)$ was measured on only $10 \%$ of depressions ( 9 dolines) and the average value was $39 \mathrm{~m}$.

The semiaxes of length and width show a certain asymmetry, above all the former; this fact is testified also by the average length ratio RLEN $_{[43]}=$ $1.63)$ and the average width ratio $\left(\right.$ RWID $\left._{[44]}=1.32\right)$. It is an index of internal asymmetry, that is, a measurement of the eccentricity of the swallow. In any case the asymmetry is not great and this is confirmed by the product of symmetry $\left(\mathrm{PSIM}_{[46]}\right)$ which shows average values equivalent to 2.16.

The doline depth is around $8-10 \mathrm{~m}$ (average maximum depth $\left(\operatorname{HMAX}_{[37]}\right)$ is $10.5 \mathrm{~m}$; close depression depth $\left(\mathrm{HDOL}_{[38]}\right)$ is $\left.8.18 \mathrm{~m}\right)$. The average slope of doline sides $\left(\mathrm{ICON}_{[34]}\right)$ is $19^{\circ}$.

The average doline perimeter $\left(\operatorname{PLAN}_{[1]}\right)$ is $232 \mathrm{~m}$, very near to the median $(214 \mathrm{~m})$. Its delimitation and measurement on the map proved to be quite easy, the perimeter usually being well delimited by contour lines and recognisable. The planimetric position error resulted as much as a dozen meters (about $2 \mathrm{~mm}$ on the map), while the altimetric error is within $5 \mathrm{~m}$, equivalent to the contour line interval.

The average area of doline $\left(\mathrm{ADOL}_{[13]}\right)$ is $4,105 \mathrm{~m}^{2}$; this value is somewhat different from median which is $3,000 \mathrm{~m}^{2}$. The planimetric area of dolines is, in fact, extremely variable and ranges from 250 to $20,000 \mathrm{~m}^{2}$.

The average area of the surface of internal runoff (ARUN ${ }_{[15]}$ ) resulted to be $19,338 \mathrm{~m}^{2}$ with the median value equivalent to $15,875 \mathrm{~m}^{2}$. It is about 5 times wider than the doline surface. 
The directional parameters were not measured. As a matter of fact, $45 \%$ of dolines have $\mathrm{RL} / \mathrm{W}_{[45]}$ less than 1.3, not significant in determining direction (according to Williams), therefore the maximum diameter direction $\left(\mathrm{DDIR}_{[16]}\right)$ and the length axis sense $\left(\operatorname{LSEN}_{[19]}\right)$ were not taken in account.

As regards the perimeter sense $\left(\mathrm{PSEN}_{[18]}\right)$ and the bottom sense $\left(\mathrm{FSEN}_{[17]}\right)$, we found that the differences in elevation along the perimeter were less than the measurement error, so the directional measurements were expected to be worthless.

The maximum and minimum elevations of the border $\left(\operatorname{PMAX}_{[20]}\right.$, PMIN $\left._{[21]}\right)$ are quite similar being respectively $1,301 \mathrm{~m}$ and $1,299 \mathrm{~m}$ in average. The average perimeter depth $\left(\operatorname{HPER}_{[36]}\right)$ is, in fact, $2.3 \mathrm{~m}$. The total difference in elevation of the perimeter $\left(\mathrm{PDEN}_{[24]}\right)$ was not measured because there were not enough spot heights on the border. This is also why the articulation index (IART $[51])$ and the relative articulation index $\left(\operatorname{IARR}_{[52]}\right)$ were not calculated.

The ideal diameter $\left(\operatorname{DIDE}_{[26]}\right)$ resulted as $65 \mathrm{~m}$, that is equivalent to $\mathrm{DAVE}_{[25]}$. This fact seems to demonstrate that this parameter does not enable one to show the light asymmetry that the dolines have, as was confirmed before. In fact the equivalent circumference shows a difference from the average perimeter length $\left(\mathrm{PLEN}_{[1]}=232 \mathrm{~m}\right.$; $\left.\mathrm{CEQU}_{[27]}=205 \mathrm{~m}\right)$; the circumference of the circumscribed circle $\left(\mathrm{CCIR}_{[28]}=253 \mathrm{~m}\right)$ is greater than the two former attributes, as is normal. The circularity index $\left(\mathrm{ICIR}_{[41]}\right)$ has a value of 1.12 , which indicates a certain perimeter symmetry in dolines. This datum does not tally with the elongation ratio $\left(\mathrm{RL} / \mathrm{W}_{[45]}\right)$ which is 1.52 (median $\left.=1.4\right)$, and shows the presence of light asymmetry.

The cross section ratio $\left(\mathrm{RH} / \mathrm{D}_{[47]}\right)$ shows average values equivalent to 0.16 and a median of 0.15 . The distribution of this value is low with a maximum value of 0.41 and minimum of 0.04 . This should indicate that evolution began at the same time for the majority of the dolines.

Lastly, it was not possible to evaluate from the map the volume $\left(\operatorname{VOLU}_{[53]}\right)$ and, consequently, the volumetric depth $\left(\mathrm{HVOL}_{[40]}\right)$.

\subsection{The Borgo Grotta Gigante area in the Classical Karst of Trieste}

The dolines have been analysed in the area covered by two topographical maps on a scale 1:5,000 n¹10052, "Prosecco" and n' 110063, "Borgo Grotta Gigante" of the Carta Tecnica Regionale of the Friuli-Venezia Giulia Region.

These two maps comprise a surface area of $18.024 \mathrm{~km}^{2}$, being elongated W-E for $6.488 \mathrm{~km}$ and N-S for $2.788 \mathrm{~km}$.

The studied area is limited by the meridians of longitude $13^{\circ} 42^{\prime} 30^{\prime \prime} \mathrm{E}$ and $13^{\circ} 47^{\prime} 30^{\prime \prime} \mathrm{E}$ and by the parallels of latitude $45^{\circ} 42^{\prime} 00^{\prime \prime} \mathrm{N}$ and $45^{\circ} 43^{\prime} 30^{\prime \prime} \mathrm{N}$. 
The mapped area is in the southern Classical Karst, a few kilometers north of Trieste.

Since in the south-western sector there appear to be no dolines for a surface area of about $5 \mathrm{~km}^{2}$, the studied area $\left(\mathrm{KARE}_{[59]}\right)$ extends for about 13 $\mathrm{km}^{2}$. Here a few more than 500 dolines $\left(\mathrm{DNUM}_{[60]}\right)$ are detectable, for an average density of about 40 dolines $/ \mathrm{km}^{2}$ (DDEN $\left.[61]\right)$. Nevertheless, due to random distribution, areas with different densities between 0 and 18 dolines/0,25 $\mathrm{km}^{2}$ are distinguishable.

The sum of the surfaces of the dolines represents about $11 \%$ of the total surface area (about 15\% if the area without dolines cited above is excluded) $\left(\mathrm{APER}_{[63]}\right)$. So the index of pitting (IPIT $\left.[62]\right)$ is 6.66 .

Since the dolines, mostly of bowl shape, open on a nearly flat plateau (average slope of the plateau surface ranging from $1 \%$ to $10 \%$ ) it is not possible to detect on the maps the divides of the closed basins and it is difficult in general to reach a precise estimation of most of the altimetric parameters. Only the doline depth, that is the difference in elevation between the perimeter and the lowest point of the bottom, has been established, where possible. In fact the contours with an interval of $5 \mathrm{~m}$ and the dashed contours of some areas with an interval of $1 \mathrm{~m}$, do not generally enable identification of the border of the basins, which are evidenced by the bases of the wedges showing the scarps. Thus, when the contours were not sufficient for identification of the border, wedges were utilised.

The evaluation of all the main parameters has been done only for dolines with an average diameter $\left(\mathrm{DAVE}_{[25]}\right)$ greater than $100 \mathrm{~m}$. In fact the mapped dolines, ranging from $15 \mathrm{~m}$ and $550 \mathrm{~m}$ in diameter, show that $94 \%$ of diameters are between $20 \mathrm{~m}$ and $100 \mathrm{~m}$; something less than $5 \%$ demonstrate larger diameters and a little more than $1 \%$ show smaller ones. Between the dolines of the main group more than $90 \%$ show sub-circular plan shapes; the remainder show elongated and irregular forms, sometimes derived from the fusion of two dolines, or through human changes; some probably originated from collapse. For this group, due to the predominance of the sub-circular forms and the variability of the elongated few, only the average diameter of the basin has been taken into consideration.

Firstly the UTM latitudes, UTM longitudes, elevations of the bottom, diameters and depths of a sample of 507 dolines have been taken into consideration. While the elevations of the bottoms have been estimated for all, although approximately when an elevation point is lacking, the depths have been evaluated for only 261 dolines. In fact, in many of the dolines where a spot height is missing on the bottom, either none or just one contour is drawn on the slopes. If one considers that the interval is 5 meters, the unspecified depths should range from 10 to less than 5 meters. 
The elevations of the bottoms, mostly varying from $210 \mathrm{~m}$ and $300 \mathrm{~m}$ a.s.l., show two well distinct maxima at $245 \mathrm{~m}$ and $280 \mathrm{~m}$ separated by a minimum between $250 \mathrm{~m}$ and $260 \mathrm{~m}$ a.s.l.

The statistical analyses of the dimensional parameters manifest the existence of a dominant population with diameters ranging from $20 \mathrm{~m}$ to $100 \mathrm{~m}$, and perhaps one or more populations of larger basins, not well defined because of the small number of these dolines. To gain further knowledge of these aspects it would be necessary to expand the analyses to all the Classical Karst.

Inside the main population the frequency distribution of the mean diameter $\left(\mathrm{DAVE}_{[25]}\right)$ shows the highest values between $30 \mathrm{~m}$ and $50 \mathrm{~m}$ (fig. 16). The histogram shows a bell shape, with a gentler slope towards the highest values.

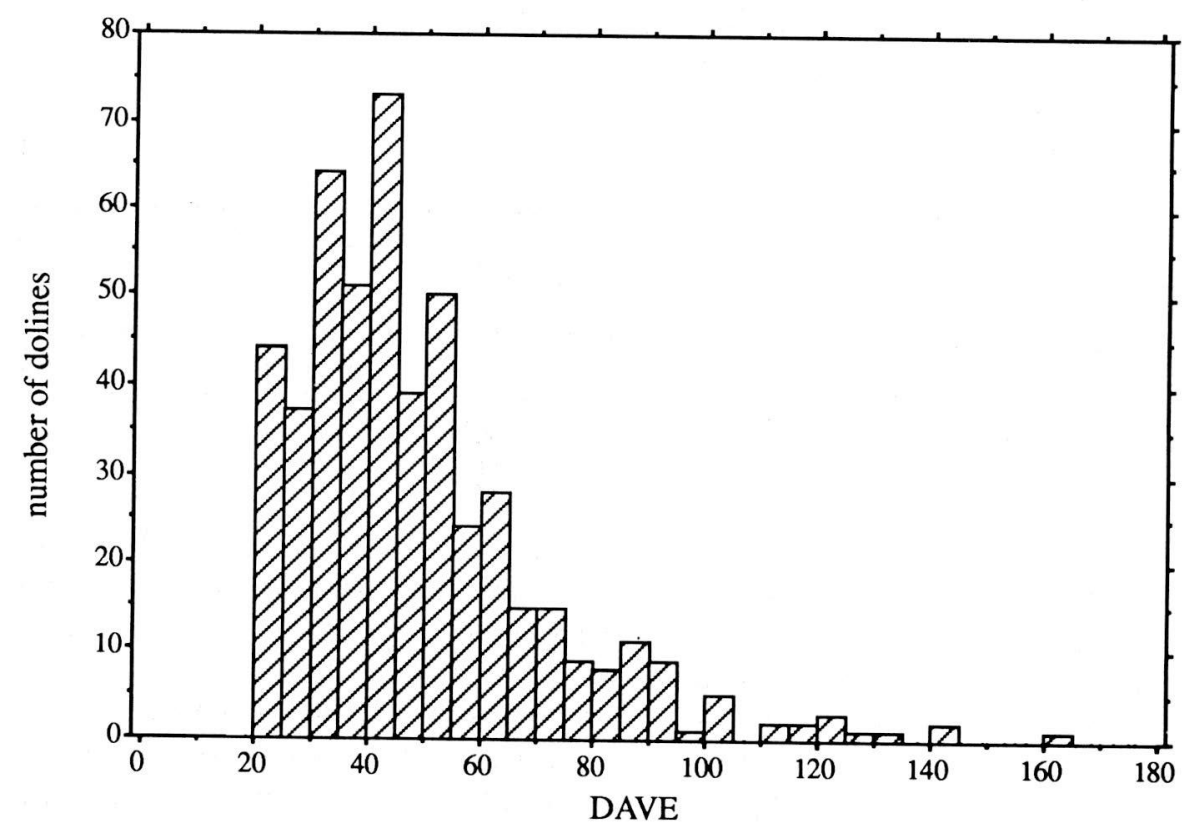

Fig. 16 - Frequency distribution histogram of the dolines of Carso di Trieste based on the average diameters comprised of from 20 to 180 meters. The main population is between 20 (or probably a lower value of smaller forms not considered because they are not represented in the maps) and about $100 \mathrm{~m}$. The highest classes are between 30 and $50 \mathrm{~m}$.

The main population depths range between $2 \mathrm{~m}$ and $24 \mathrm{~m}$, with a frequency distribution similar to the previous one and the highest peak close on 4-6 m.

In the depth / average diameter ratio $\left(\mathrm{RH} / \mathrm{D}_{[47]}\right)$ the first represents a little more than $1 / 10$ of the second $(y=0.1 x+1.37 m)$, with an $r^{2}$ value of 0.78 (fig. 17). 


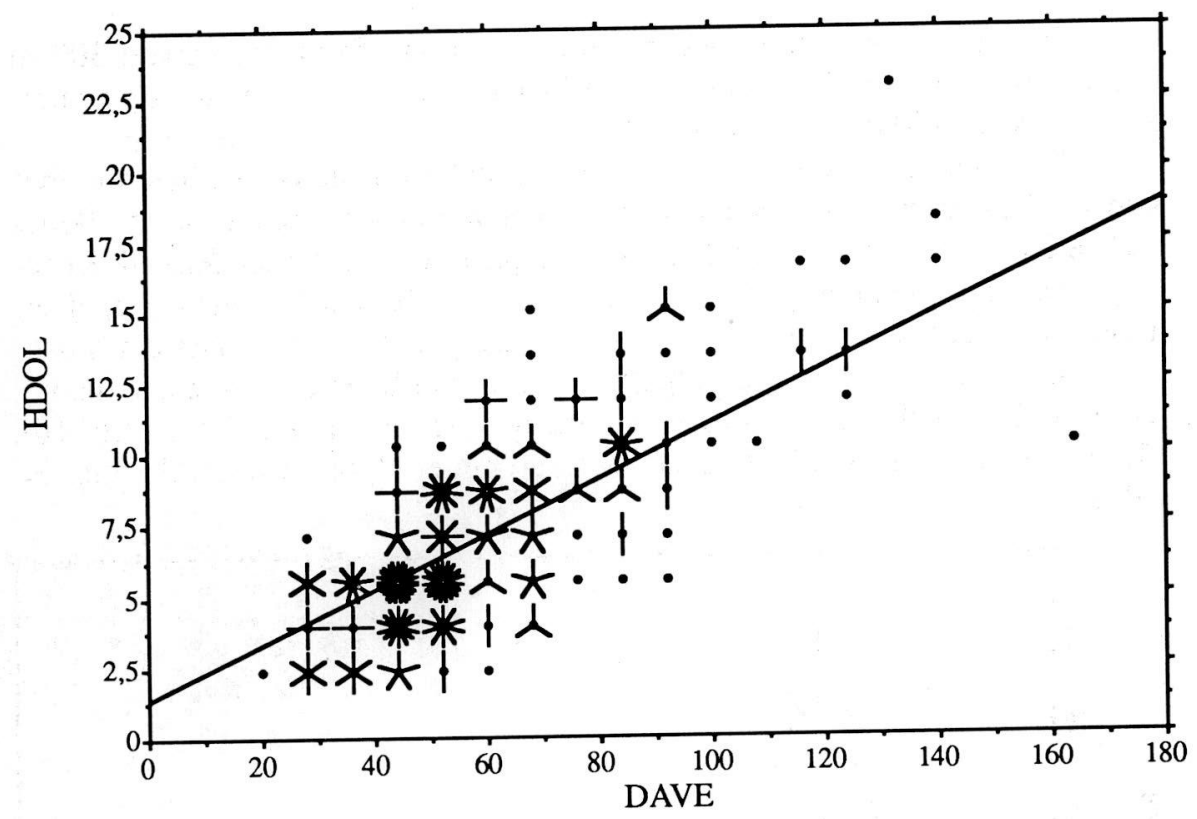

Fig. 17 - Correlation depth / diameter ratio $\left(\mathrm{RH} / \mathrm{D}_{[47]}\right)$. The linear regression shows that the first represents a little more than $1 / 10$ of the second $\left(y=0.1 x+1.37 \mathrm{~m}\right.$.), with a $\mathrm{r}^{2}$ value of 0,78 . The dispersion of the values is high especially for the dolines with diameters of about $50-70 \mathrm{~m}$. Points with bars are representative of more dolines with same values.

The dimensional parameters of the larger dolines show a much greater variability. The dispersion of the values and the scarce significance of the sample, consisting of just 21 dolines, have conferred little significance to the statistical analysis. The results are therefore not discussed here.

Even though we do not develop the complex problem of spatial analyses of this karst area here, we feel that it will be useful to outline some preliminary observations on the plan distribution of the central points of the dolines (fig. 18). In this area the distribution is neither uniform nor random, but rather a reticle with some clusters. Such a reticle shows circular or polygonal meshes or chains, with diameters ranging from $200 \mathrm{~m}$ to $1 \mathrm{~km}$. Inside the meshes there is a low density of dolines. The inner "empty spaces" are often represented by larger dolines or by dome-shaped summits.

It is possible to formulate three hypotheses, not necessarily alternative, about the origin of the belts with a higher density of dolines: these may be linked with strips of more karstifiable rocks (for lithological characters or for density of fractures), or represent the evolution of an old surface drainage network first developed in the cover rocks or even be linked with the under- 
ground karst network. These hypotheses encourage extension of the analysis to the entire karst region.

Among orientations resulting from the alignments of dolines the most notable is the Dinaric direction (NW-SE) followed by those N-S and NE-SW. Some N-S alignments seem to show a small right-hand horizontal throw perhaps linked with transcurrent faults corresponding to the Dinaric direction.

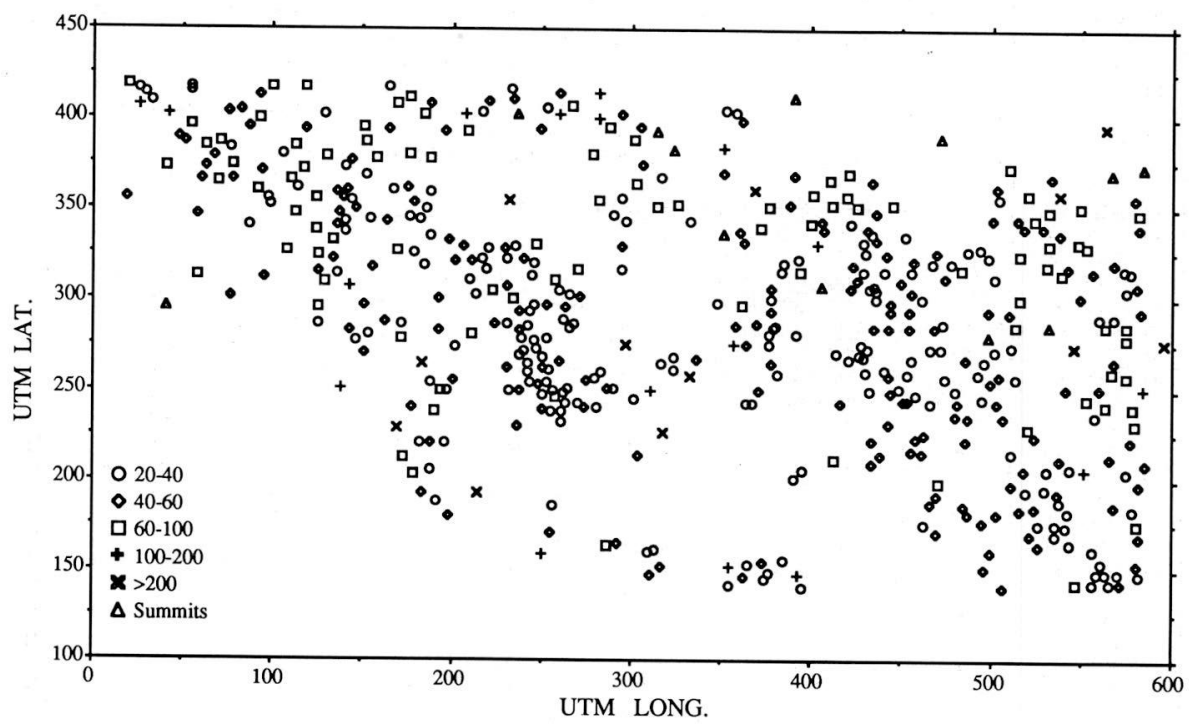

Fig. 18 - Spatial plan distribution of dolines of different dimensional classes in the area of Borgo Grotta Gigante (Carso di Trieste) covered by two topographical maps on a scale 1:5,000. The scale values in both axes are in decameters. It is possible to distinguish the random distribution and the variable density. The doline pattern forms a reticle with almost circular meshes or chains, with diameters ranging from $200 \mathrm{~m}$ to $1 \mathrm{~km}$. Inside the meshes there is a low density of dolines. The inner "empty spaces" are often represented by larger dolines or by dome shaped summits. The most notable direction resulting from the alignments of more dolines is the Dinaric one (NW-SE), followed by N-S and NE-SW. 
Table I

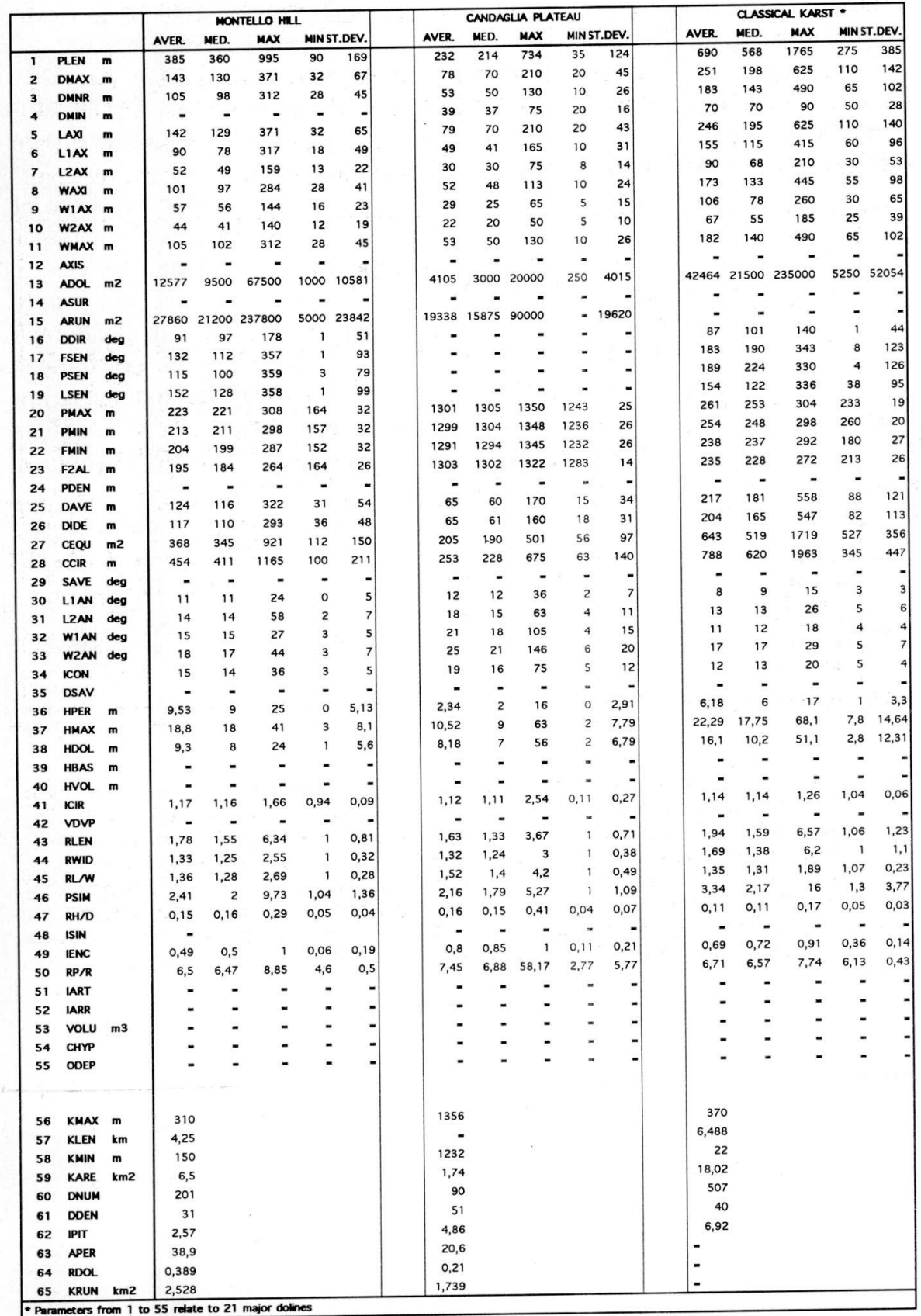




\section{SKETCH OF A SURVEY FORM FOR A DATA BASE ON THE NATURAL PARAMETERS OF A DOLINE}

Each doline represents a small landscape unit corresponding to a "hydromorphological" functional unit. For a surveyor located inside a closed basin the visual horizon is delimited by the system of slopes.

The morphometrical parameters listed above consider only the shape of the hollows and not their natural and environmental characteristics. It is possible to determine and analyse countless landscape and environmental aspects.

In the list drawn out below we do not claim to be exhaustive, but simply to furnish an example of some of the most important aspects of the landscape and the natural and environmental characteristics of a population of dolines that could be considered inside a "data-base". Some of these parameters are quantitative, others semi-quantitative or simply descriptive. In the case of elements such as geology, soil and vegetation it would be possible to compile further, more specialist forms.

The list below is partly derived from a paper of CASTIGLIONI (1991).

\section{Coordinates and altitudes}

LONG ............UTM longitude co-ordinate

LATI...............UTM latitude co-ordinate

BALT ..............bottom altitude

LRAL .............. lowest rim point altitude

HRAL .............highest rim point altitude

HALT ..............basin highest point altitude

\section{Simple morphometrical parameters}

DMAX...........doline maximum diameter

DAVE..............doline average diameter

LAXI...............basin longest axis length

DDIR. ............doline maximum diameter direction

ADOL ............doline area

ARUN ..............area of internal runoff

HDOL .............enclosed depression depth

HMAX ............maximum depth

\section{Bottom characteristics}

BMFL ............flat

BMSU .............sublevelled

BMCO .............concave

BMFU ............funnel shaped 


\section{Slope characteristics}

BARO bare rock $(\%)$

TERS terraces

SCAR scarps

\section{Geological and geomorphological elements}

MLIU main lithological units

THST thickness of strata

SDST strike and dip of strata

THBD thickness of bottom deposits

CHBD characteristics of bottom deposits

\section{Pedological elements}

MSTY main soil type

RTHS range of soil thickness

$\mathrm{PCHH}$. presence of characteristic soil horizons

\section{Hydrological elements (natural and artificial)}

HYSS small springs

HYWE well

HYCI cistern

HYWS water stagnation

\section{Meteorological elements (they require a special monitoring)}

MTTD ............difference in mean temperatures at the edge and the bottom

\section{Landscape features}

PTBU presence and types of buildings

BWAL dry-wall on the bottom

SWALL dry-wall on the slopes

\section{Natural vegetation}

SWILD...........semi wild with shrub

WILD ...............wild

GRASS ..........grass

WOOD .............wood

\section{Wood type}

WTTW thermophile wood

WTMW mesophile wood

WTLW microthermic wood 


\section{Cultivation \\ ARAB .............arable land \\ ORCH .............orchard \\ VINE..............vine yard \\ GARD ............market garden \\ MEAD ...........meadow}

Bottom (north facing slope, south f.s., east f.s., west f.s. ) soil use (for each)

BSCC (NSCC, SSCC, ESCC, WSCC)...................ultivation

BSGR (NSGR, SSGR, ESGR, WSGR)............... grazing

BSCP (NSCP, SSCP, ESCP, WSCP) ......................opse

BSOH (NSOH, SSOH, ESOH, WSOH)................ orchard

BSVI (NSVI, SSVI, ESVI, WSVI) ......................vine yard

BSMA (NSVMA, SSMA, ESMA, WSMA) ........market garden

BSHA (NSHA, SSHA, ESHA, WSHA)..............hay

BSWD (NSWD, SSWD, ESWD, WSWD) .............ood

BSWL (NSWL, SSWL, ESWL, WSWL) .............wild

\section{Human impact}

FSDE ............filling solid deposits

WADI...............waste disposal

SEWA ….........sewage

QASS .............quarry of soil sediments

LIQA...............limestone quarry

\section{FINAL COMMENTS}

The main goal of this paper was not to give standard analytical methods, but to give an ordered list with precise definition of most of the morphometrical parameters found in literature.

Through this work we hope to encourage a renewal of research on dolines, as it is believed that both morphometric and spatial analysis applied to karst areas will give a lot of useful information leading to greater knowledge both of the geomorphological history of each morphokarst unit, and of the structure of karst acquifers.

We will be grateful to all the karstologists who will inform us about progress in morphometrical analysis and related papers. 


\section{BIBLIOGRAPHY}

Agnesi V., Macaluso T., Meneghel M., Sauro U. (1989) - Geomorfologia dell'area carsica di S.Ninfa. In "I Gessi di Santa Ninfa", Memorie dell'Istituto Italiano di Speleologia, 3 (2), 23-48.

AUBERT D. (1966) - Structure, activité et evolution d'une doline. Bulletin de la Societé Neuchateloise des Sciences Naturelles, 89, 113-120.

Baboç K., Palmentola G., Sanso P. (1991) - Primi risultati dello studio quantitativo delle forme carsiche epigee dei dintorni di S. Marco in Lamis. Itinerari Speleologici, s. 2, 5, 87-95.

Balazs D. (1973) - Relief types of tropical karst areas. Proceedings of IGU symposium on karst morphogenesis Szeged, Attila Jozsef University, Hungary, 1-22.

BARANY-KeVei I., Mezosi G. (1991) - Further morphometrical data from some important hungarian karst areas. Proceedings of the International Conference on Environmental Changes in Karst Areas, IGU-UIS, Quaderni del Dipartimento di Geografia, Università di Padova, 13, 137-142.

BECK B.F. (ed.) (1984) - Sinkholes: their geology, engineering and environmental impact. Florida Sinkhole Research Institute. A.A. Balkema, Rotterdam, 429 pp.

Berry B.J. L., MARble D.F. (1968) - Spatial analysis., Prentice-Hall, Englewood Cliffs, New Jersey, 512 pp.

Biancotti A., Motta M. (1988) - Morfotettonica dell' altopiano delle Mànie e zone circostanti (Liguria Occidentale). Suppl. Geografia Fisica e Dinamica Quaternaria, 1, 45-68.

BRoOK G.A. (1981) - An approach to modelling karst landscapes. South African Geogr. Journal, 63, 1.

Brook G.A , Mitchelson R.L. (1981) - Single and double Fourier series analysis of Cockpit Karst in Puerto Rico. Proceedings of the 8th International Speleological Congress (Bowling Green), 53-55.

CAstiglioni B. (1991) - Some morphometric and environmental aspects of dolines in Berici Hills (Vicenza, Italy). Proc. Intern. Conf. on Environmental Changes in Karst Areas - IGU-UIS, Quaderni del Dip. Geogr. Univ. Padova, 13, 143-155.

Castiglioni G.B. (1960) - Atlante Internazionale dei Fenomeni Carsici, Foglio 2 "Bosco del Cansiglio". Univ. di Padova, Ist. Geogr.

CAstiglioni G.B. (1964) - Forme del carsismo superficiale sull'altopiano del Cansiglio. Atti Istituto Veneto di Scienze, Lettere ed Arti, 122, 327-344.

Castiglioni G.B. (1979) - Geomorfologia. UTET, Torino, 436 pp.

Cavallin A. (1980) - Assetto strutturale del Massiccio Cansiglio-Cavallo (Prealpi Carniche Occidentali). AIIG, Atti $2^{\circ}$ convegno studi territ. prov. Pordenone (Piancavallo, 19-21 ottobre 1979), 15-32.

CELI M. (1991) - The impact of bombs of World War I on limestone slopes of Monte Grappa. Proc. Intern. Conf. on Environmental Changes in Karst Areas - IGU-UIS, Quaderni del Dip. Geogr. Univ. Padova, 13, 279-287. 
CHORLEY R.J. (1972) - Spatial Analysis in geomorphology. Methuen, London, 394 pp.

CHow W.T. (1964) - Handbook of applied hydrology. McGraw Hill Book, N.Y.

Clark P.J., Evans F.C. (1954) - Distance to nearest neighbour as a measure of spatial relationships in populations. Ecology, 35, 445-453.

Cole J.P., King C.A.M. (1968) - Quantitative Geography. Wiley, London, 692pp.

Coleman A.M., BALCHIN W.G.V. (1959) - The origin and development of surface depressions in the Mendip Hills. Proceedings of the Geologists Association, 70, 291-309.

Comes, P., Graganese V., Rotondo D. (1992) - La Grave di Santa Lucia in Agro di Monopoli (Bari). Itinerari Speleologici, 6, 55-78.

Cottam G., Curtis J.T., CATANA A.J. (1957) - Some sampling characteristics of a series of aggregated populations. Ecology, 38, 610-622.

CrAmer H. (1941) - Die Systematik der Karstdolinen. Neues Jahrbuch für Mineralogie, Geologie und Paläontologie, 85, 293-382.

CuCCHI F. (1978) - Indagini strutturali su alcune cavità del Montello Nordorientale (TV). Mondo sotterraneo, 2 (1), 13 pp.

CUCCHI F. , FORTI F., UlCigRAI F. (1975) - Relazioni tra tettonica e morfogenesi di doline del Carso Triestino e Monfalconese. Atti e Memorie della Commissione Grotte "E. Boegan", 15, 57-71.

CURRAY J.F. (1956) - The analysis of two-dimensional orientation data. Journal of Geology, 64, 117-131.

CVIJIC' J. (1893) - Der Karstphänomen. Geographische Abhandlungen, 5, 217-329.

CVIJIC' J. (1925) - Types morphologiques des terrains calcaires. C. R. Académie des Sciences (Paris), 180, 592, 757, 1038.

DACEY M.F., TUNG T. (1962) - The identification of randomness in point patterns. Journal Regional Sciences, 4, 83-96.

DAl PIAZ G. (1910) - Altipiano del Cansiglio e Regione circostante. Bollettino Regio Comitato Geologico d'Italia, 41.

DAY M.J. (1976) - The morphology and hydrology of some Jamaican karst depressions, Earth Surface Process, 1, 11-129.

DAY M.J. (1977a) - Surface hydrology within polygonal karst depressions in northern Jamaica. Proceedings of the 7th International Speleological Congress (Sheffield), 143-146.

DAY M.J. (1977b) - Surface roughness in tropical karst terrain. Proceedings of the 7th International Speleological Congress (Sheffield), 139-143.

DAY M.J. (1978) - Morphology and distribution of residual limestone hills (mogotes) in the karst of northern Puerto Rico. Bulletin of Geological Society of America, 89, 426432.

DAY M.J. (1979) - Surface roughness as a discriminator of tropical karst styles, Zeitschrift für Geomorphologie. Suppl-Band, 32, 25-34.

DAY M.J. (1983) - Doline morphology and development in Barbados. Annals of Association of American Geographers, 73 (2), 206-219. 
DAY M.J. (1984) - Predicting the location of surface collapse within karst depression: a Jamaican example. In BECK B.F. (ed.), "Sinkholes: their geology, engineering and environmental impact", Balkema, Rotterdam, 147-151,

DE NARDi A. (1965) - Schema tettonico del Massiccio del Cansiglio-Cavallo nelle Prealpi Friulane Occidentali. Memorie Accademia Patavina di Scienze Lettere e Arti, 76, 137-147.

DE NARDI A. (1977) - Il Cansiglio-Cavallo. Lineamenti geologici e morfologici. Azienda Foreste Regione Friuli - Venezia Giulia, Azienda Stato Foreste Demaniali, 137 pp.

DoORnKAMP J.C., KING A.M. (1971) - Numerical analysis in geomorphology - an introduction. Arnold, London, 372pp.

DRAKE J., FORD D.C. (1972) - The analysis of growth patterns of two generation populations: the example of karst. Canadian Geographer, 16 (4) 381-385.

Dublyansky V.N., Ilyokhin V.N., Lobano Y.E. (1969) - Some problems of karst morphometry. Studies in Speleology, 7, 17-22.

EvANS I.S. (1972) - General Geomorphometry, derivates of altitude and descriptive statistics. In CHORLEY R.J. (1972) "Spatial Analysis in Geomorphology", Methuen, London, 17-90.

FERASIN F. (1958) - Il "complesso di scogliera" cretaceo del Veneto centro-orientale. Memorie Istituto Geologia Mineralogia, Università di Padova, 21, 54 pp.

FERMOR J. (1972) - The dry valleys of Barbados: a critical review of their pattern and origin. Transactions of the Institute of British Geographers, 57, 153-165.

FERrarese F., MENEGHel M. (1992) - Aspetti dell' influenza strutturale sulla morfogenesi carsica nel Montello (Treviso). Atti e Mem. Comm. Grotte "E. Boegan”, 30, 41-45.

Feruglio G. (1911) - Altopiano del Cansiglio e la sua morfologia. Atti Società Italiana Progresso Scienze, $5^{\mathrm{a}}$ riunione, ott. 1911, Roma, 849-850.

FORD D.C.(1964) - Origin of closed depressions in the central Mendip Hills. Proceeding of the 20th International Geographical Congress, Abstracts, 105-106.

FORD D., WILLIAMS P.W. (1989) - Karst geomorphology and hydrology. Unwin Hyman, London, 601pp.

ForTI F. (1972) - Osservazioni geomorfologiche sulle doline del Carso Triestino. Atti $11^{\circ}$ Congresso Nazionale Speleologia, Genova, Nov. 1972, 239-243.

GAMS I. (ed.) (1973) - Slovenska Kraska Terminologia. Zveza Geografskih Institucij Jugoslavije, Kraska Terminologija Jugoslavanskih Narodov, 1, 77 pp.

GERLETti M. (a cura di) (1974) - Indagini sul Lago di Garda. Quaderni IRSA, 18, Roma. $270 \mathrm{pp}$.

GETIS A. (1964) - Temporal land-use patterns analysis with the use of nearest neighbour and quadrant methods. Annals of Association of American Geographers. 54, 391-399.

GORBUNOVA K. A. (1968) - Morphometric character of a carbonate karst (for the case of a basin of the middle part of the R. Usva) [Russia]. In Karst Urala i Priural'ya, Perm, 33-39.

Gortani M. (1908) - Appunti per una classificazione delle Doline. Mondo Sotterraneo, 115-116. 
Gortani M. (1959) - Compendio di Geologia, Geodinamica esterna. Del Bianco, Udine, $478 \mathrm{pp}$.

GoudiE A. (ed.) (1981) - Geomorphological Tecniques. Allen \& Unwin, London, 395 pp.

GRAY J.M. (1974) - On the use of chi-square on percentage orientation data: discussion. Bullettin of the Geological Society of America, 85, 833.

Guenther W.C. (1964) - Analysis of variance. Prentice-Hall, Englewood Cliffs, New Jersey, $199 \mathrm{pp}$.

GUNN J. (1977) - A model of the drainage system of a poligonal karst depression in the Waitomo area, North Island, New Zealand. Proceedings of the 7th International Speleological Congress (Sheffield), 225-229.

HaBIC P. (1990) - Cetvrti skup geomorfologa Jugoslavije. Pirot, 20-23 June 1989, Geographical Faculty of Beograd, 55-60.

Hagget P., Chorley R. J. (1969) - Network Analysis in Geography. Arnold, London, 348 pp.

HAY A.M., ABDel Rahmann M.A. (1974) - Use of the chi-square for the identification of peaks in orientation data: comment. Bullettin of the Geological Society of America, 85, 1963-65.

HORTON R.E. (1945) - Erosional development of streams and their drainage basins: Hydrophysical approach to quantitative morphology. Bullettin of the Geological Society of America, 56, 275-370.

HOWARD A.D. (1968) - Stratigraphic and structural controls on landform development in the central Kentucky Karst. Bullettin of Natural Speleological Society, 30, 95-114.

JEnNings J.N. (1963) - Collapse doline. Australian Landform Example $N^{\circ} 1$. Australian Geographer, 9, 122-123.

JENNINGS J.N. (1971) - Karst. MIT Press, London, 253 pp.

JENNINGS J.N. (1972) - The character of tropical humid karst. Zeitschrift für Geomorphologie, 16, 336-341.

JENNINGS J.N. (1975) Doline morphometry as a morphogenetic tool: New Zealand examples. New Zealand Geographer, 31, 6-28.

JENNINGS J.N. (1985) - Karst geomorphology. Blackwell, Oxford, 293 pp.

JENNINGS J.N., BIK M.J. (1962) - Karst morphology in Australian New Guinea. Nature, 194, 1036-1038.

KEMMERLY P.R. (1976) - Definitive doline characteristics in the Clarksville quadrangle, Tennessee. Bullettin of the Geological Society of America, 87, 42-46.

KEMMERLY P.R. (1982) - Spatial analysis of a karst depression population: clues to genesis. Bullettin of the Geological Society of America, 93, 1078-1086.

KemMerLy P.R., Towe S.K. (1978) - Karst denudation in a time context. Earth Surface Process, 35, 355-362.

KING L.J. (1962) - A quantitative expression of the pattern of urban settlements in selected areas of the United States. Tijdsch. Voor Econ en Soc. Geographie, 53, 1-7.

KING L.J. (1969) - Statistical analysis in geography. Prentice-Hall, Englewood Cliffs, New Jersey, 288 pp. 
KRUMBeIN W.C. (1939) - Preferred orientation of pebbles in sedimentary deposits. Journal of Geology, 47, 673-706.

Krumbein W.C., Graybill F.A. (1965) - An introduction to statistical models in geology. McGraw Hill Book, New York, 475 pp.

LA VAlle P. (1966) - Variacion especial de la karstificacion relativ en Kentuky sur-central. Proceedings of UGI Conferencia Regional Latinoamericana, Mexico, 1965, 3, 267-276

LA VALLE P. (1967) - Some aspects of linear karst depression development in south-central Kentucky. Annals of Association of American Geographers, 57, 49-71.

LA VAlle P. (1968) - Karst depression morphology in South Central Kentuky. Geografiska Annaler, 50 A, 94-108.

LING CHANG F. (1984) - Application of distances between nearest neighbours to the study of karst. Carsologica Sinica, 3 (1), 97-101.

LOZINSKI W., Von (1907) - Die Karsterscheinungen in Galazisch-Podohen, J. Geol. Reichsamst, Wien, 683-726.

MAGALDI D., SAURO U. (1982) - Landforms and soil evolution in some karstic areas of the Lessini Mountains and Monte Baldo (Verona, Northern Italy). Geografia Fisica e Dinamica Quaternaria, 5, 82-101.

Massimi G. (1979) - Classificazioni delle doline. In Massimi G., Mazzara P., "Considerazioni sul fenomeno carsico con particolare riguardo all'Appennino Abruzzese”, Art. Graf. Barretta, Chieti, 64 pp..

MC CONNEll H.J., HoRn J.M. (1972) - Probabilities of surface karst. In CHORLEY R.J. (ed.) "Spatial analysis in geomorphology", Methuen, London, 135-163.

MEZÖSI G., BARANY I., TOTH I. (1978) - Karstmorphometrische Untersuchungen im Gebirge Aggtelek. Acta Universitatis Szegediensis, Acta Geographica, 18, 131-140.

Mietto P., SAURo U. (1989) - Grotte del Veneto. La Grafica, Vago di Lavagno, 415 pp.

OGDEN A. (1984) - Methods for describing and predicting the occurrence of sinkholes. In BECK B.F. (ed.), "Sinkholes: their geology, engineering and environmental impact", Florida Sinkhole Research Institute. Balkema, Rotterdam, 429 pp.

PALMQUIST R.C. (1976) - Distribution and density of dolines in areas of mantled karst in Hydrologic problems in karst regions. In DilamaRTER R.R., Csallany S.C.(eds.), Western Kentuky University Press, Bowling Green, Ky, 117-129.

PALMQUIST R.C. (1979) - Geologic controls on doline characteristics in mantled karst. Zeitschrift für Geomorphologie, Suppl. Band 32, 90-136.

PATERSON K. (1980) - Closed depression in limestone areas: some teaching approaches for the physical geographer. Geography, 65 (287), 107-118.

Pielou E.C. (1969) - An introduction to mathematical ecology. John Wiley \& Son, New York, $286 \mathrm{pp}$.

PINCUS H.J. (1953) - The analysis of aggregates of orientation data in the earth sciences. Journal of Geology, 61, 482-509.

PINCUS H.J. (1956) - Some vector and arithmetic operations on two-dimensional orientation variates, with applications to geological data. Journal of Geology, 64, 553-557. 
SACCARDO A. (1885) - Ricerche intorno alle erosioni del Montello. Atti Società VenetoTrentina Scienze Naturali, 9 (2), 16 pp.

Sauro U. (1973) - Il Paesaggio degli alti Lessini. Studio geomorfologico. Museo Civico Storia Naturale di Verona, Mem. f. s. 6, 161 pp.

SAURO U. (1974) - Aspetti dell' evoluzione carsica legata a particolari condizioni litologiche e tettoniche negli Alti Lessini. Bollettino Società Geologica Italiana, 93, 945969.

SAuro U. (1979) - Morfologia carsica. In CAStiglioni G.B., "Geomorfologia",UTET, Torino, 208-254.

SAURo U. (1991) - A Polygonal karst in Alte Murge (Puglia, Southern Italy). Zeitschrift für Geomorphologie, N.F. 35/2, 207-223.

SEgRe A.G. (1948) - I fenomeni carsici e la speleologia del Lazio. Pubblicazioni dell'Istituto di Geografia dell'Università di Roma, A, 7, 236 pp.

SHREve R.L. (1966) - Statistical law of stream numbers. Journal of Geology. 74, 17-37.

Sperling C. H.B., Goudie A.S., Stoddard D.R., Poole G.G. (1977) - Dolines of the Dorset Chalklands and other areas in Southern Britain. Transactions of the Institute of British Geographers, N.S., 2, 205-223.

Stella A. (1902) - Descrizione geognostica agraria del Montello. Memorie Descrittive Carta Geologica Italiana, 11.

Strahler A.N. (1975) - Physical Geography. Wiley, N.Y., 643.

STRAHLER A.N. (1957) - Quantitative analysis of watershed geomorphology. American. Geophys. Union Transactions, 38, 913-920.

SUSTERICH F. (1985) - A method of doline morphometry and computer processing. Acta Carsologica, 13, 79-98.

SweETING M.M. (1972) - Karst landforms. Macmillan, London, 362 pp.

SwEETING M.M. (1973) - The morphology of humid tropical karst: a review. Proceedings of Geographical Association of Rhodesia, 6, 50-65.

Toniolo A.R. (1907) - Il Colle del Montello. Memorie Geografiche, 1, 257-393.

Troester J.W., White E.L., White W.B. (1984) - A comparison of sinkhole depth frequency distributions in temperate and tropical karst regions. In BECK B.F. (ed.), "Sinkholes: their geology, engineering and environmental impact", 65-73, Balkema, Rotterdam.

VINCENT P.J. (1987) - Spatial distribution of polygonal karst sinks. Zeitschrift für Geomorphologie, 31 (1), 65-72.

WERNER E. (1972) - Comments on Williams' “Illustrating morphometric analysis of karst with examples from New Guinea”. Zeitschrift für Geomorphologie, 16, 469-471.

White E.L., WhITE W.B. (1979) - Quantitative morphology of landforms in carbonate rock basins in the Appalachian Highlands. Bullettin of the Geological Society of America, 90, 385-396.

WhitE W.B. (1988) - Geomorphology and Hydrology of carbonate terrains. University Press, Oxford, 464 pp. 
Williams P.W. (1966) - Morphometric analysis of temperate karst landforms, Irish Speleology, 1, 23-31.

WILLIAMS P.W. (1971) - Illustrating morphometric analysis of karst with examples from New Guinea. Zeitschrift für Geomorphologie, 15, 40-61.

Williams P.W. (1972a) - Morphometric analysis of polygonal karst in New Guinea. Bullettin Geological Society of America, 83, 761-796.

WILLIAMS P.W. (1972b) - The analysis of spatial characteristics of karst terrains. In CHORLEY R.J., "Spatial Analisis in Geomorphology", Methuen, London, 135-163.

WiLliams P.W. (1974) - Use of chi-square on percentage orientation data: reply. Bullettin of the Geological Society of America, 85, 833-834.

Williams P.W. (1982) - Karst landforms in New Zealand. In SoOns J. SELBY M.J. (eds.) "Landforms of New Zealand", Longman, Auckland, 105-125,

Williams P.W. (1985) - Subcutaneous hydrology and the development of doline and cockpit karst. Zeitschrift für Geomorphologie, 29, 463-482.

\section{NOTES}

The main aim of this paper is to promote research on karst landforms and environments in accordance with the aims of the Commission "Environmental Changes and Conservaton in Karst Areas" of the International Geographical Union.

The research was carried out with the Italian Government funds $60 \%$ MURST "Impatto uomo-ambiente e morfodinamica in aree carsiche" and 40\% MURST "Geomorfologia strutturale ed evoluzione del rilievo in Italia e nelle aree mediterranee".

All the authors fully cooperated in the research work. In particular, A. Bondesan was mainly responsible for chapters 1,2,3,6 and 8.2; M. Meneghel for chapters 6, 7, 8.1. and the drawings; U. Sauro for chapters 1, 4, 5, 8.3 and 9. 